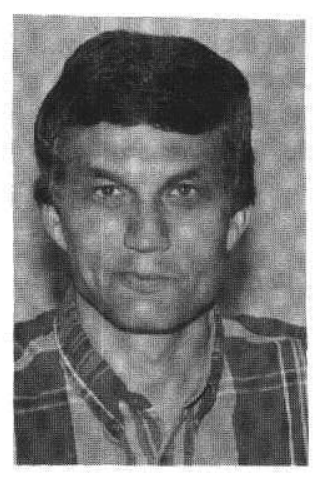

\title{
Invited Synthesis Paper: Implications of rising atmospheric carbon dioxide concentration for rangelands
}

\author{
H. WAYNE POLLEY
}

Author is an ecologist, USDA, Agricultural Research Service, 808 E. Blackland Rd., Temple, Tex. 76502. Correspondence: Wayne Polley, USDA, ARS, Grassland, Soil \& Water Research Lab., 808 E. Blackland Rd., Temple, Tex., USA 76502. Telephone: 817-770-6629. FAX: 817-770-6561.

Abstract

Extensive rangelands and other vegetation types that we know today formed while atmospheric carbon dioxide $\left(\mathrm{CO}_{2}\right)$ concentration was low (50 to $75 \%$ of today's concentration). Fossil fuel burning and deforestation and other land use changes during the last 200 years have increased $\mathrm{CO}_{2}$ concentration by about $30 \%$, to the present 360 parts per million (ppm). Atmospheric $\mathrm{CO}_{2}$ will continue to rise during the next century, possibly to concentrations that are unprecedented for the last several million years. Much of the potential importance of $\mathrm{CO}_{2}$ concentration to vegetation derives from its influence on plant carbon balance and water relations. Plants grow by assimilating $\mathrm{CO}_{2}$ that diffuses into leaves through stomatal pores. Inevitably associated with $\mathrm{CO}_{2}$ uptake is transpirational loss of water vapor through stomata. Transpiration rates usually decline as $\mathrm{CO}_{2}$ increases, while, in many plants, photosynthesis and growth increase. These "primary" responses to $\mathrm{CO}_{2}$ can lead to a multitude of changes at the plant and ecosystem levels, ranging from alteration of the chemical composition of plant tissues to changes in ecosystem function and the species composition of plant communities.

The direct physiological responses of plants to $\mathrm{CO}_{2}$ and expression of these responses at higher scales differ among species and growing conditions. Growth response to $\mathrm{CO}_{2}$ is usually highest in rapidly-growing plants that quickly export the carbohydrates formed in leaves and use them for storage or new growth and allocate a high proportion of fixed carbon to produce leaves. Growth is also more responsive to $\mathrm{CO}_{2}$ in plants with the $\mathrm{C}_{3}$ (most woody plants and 'cool-season' grasses) than $\mathrm{C}_{4}$ photosynthetic pathway (most 'warm-season' grasses). These and other differences among species could lead to changes in the composition of rangeland vegetation, but generalizations are difficult. On many rangelands, species abundances are determined more by morphological and phenological attributes that influence plant access to essential resources like nitrogen and light and reaction to fire, grazing, and other disturbances than by physiological traits that are sensitive to $\mathrm{CO}_{2}$ concentration. Species composi-

Katherine Jones prepared figures. David Briske, Hyrum Johnson, Alan Knapp, Herman Mayeux, Jack Morgan, Larry Tieszen, Charles Tischler, and 2 anonymous referees provided constructive reviews. All programs and services of the U.S. Department of Agriculture are offered on a nondiscriminatory basis and without regard to race, color, national origin, religion, sex, age, marital status, or handicap.

Manuscript accepted 28 May 1997. tion probably will be most responsive to $\mathrm{CO}_{2}$ on moderately water-limited and disturbed rangelands where multiple positive effects of $\mathrm{CO}_{2}$ on plant water relations can be expressed and competition for light is minimized. Greatest initial changes in species composition likely will occur on $\mathbf{C}_{3} / \mathrm{C}_{4}$ grasslands and at the transition between grasslands and woodlands. Plant production should also increase on water-limited rangelands, but $\mathrm{CO}_{2}$ may have little influence on production when nutrient elements like nitrogen are severely limiting.

Key Words: grasses, nitrogen, photosynthesis, primary production, transpiration, vegetation change, water use efficiency

\section{Resúmen}

Extensas áreas de pastizales y otros tipos de vegetación que ahora conocemos se formaron durante periodos de tiempo en los cuales el bióxido de carbono $\left(\mathrm{CO}_{2}\right)$ atmosférico era bajo $(50$ a $70 \%$ de la actual concentración). El uso de combustibles fósiles y la deforestación, lo mismo que diversos usos de la tierra durante los últimos 200 años han incrementado la concentración de $\mathbf{C O}_{2}$ en aproximadamente $30 \%$, hasta alcanzar las 360 partes por millón (ppm) del presente. El $\mathrm{CO}_{2}$ atmosférico continuará aumentando durante el próximo siglo, posiblemente hasta concentraciones que no tienen precedente en los últimos millones de años.

La mayor parte de las implicaciones potenciales de los cambios en concentracion de $\mathrm{CO}_{2}$ con respecto a la vegetación, se derivan de su influencia sobre el balance de carbono y las relaciones hídricas en las plantas. El desarrollo de las plantas por la asimilación de $\mathrm{CO}_{2}$ que entra en las hojas por difusión a través de los estomas. También, en forma inevitable, la pérdida de vapor de agua por transpiración a través de los estomas está asociada con la absorción de $\mathrm{CO}_{2}$. Las tasas de transpiración usualmente decrecen a medida que el $\mathrm{CO}_{2}$ se incrementa, mientras que en muchas plantas, la fotosíntesis y el crecimiento aumentan. Estas respuestas "primarias" debidas al $\mathrm{CO}_{2}$ pueden conducir a multitud de cambios a nivel de planta y de ecosistema, estos cambios pueden ir desde alteración en la composición química de los tejidos de las plantas hasta cambios en funciones dentro de los ecosistemas, y variación en la composición de especies dentro de las comunidades vegetales.

Las respuestas fisiológicas directas de las plantas al $\mathrm{CO}_{2}$, lo mismo que la expresión de esas respuestas a más alto nivel 
difieren de acuerdo a las especies y a las condiciones de crecimiento. La respuesta en crecimiento debida a $\mathrm{CO}_{2}$ es usualmente mayor en plantas de crecimiento rápido, que rápidamente exportan los carbohidratos formados en las hojas y los usan para almacenamiento o nuevo crecimiento. Estas plantas destinan alta proporción del carbono fijado para producir hojas. Respuestas en crecimiento debidas a $\mathrm{CO}_{2}$ son más frecuentes en plantas de sistema fotosintético $C_{3}$ (la mayoria de las plantas leñosas y pastos de estación fría) que en plantas de sistema fotosintético $\mathbf{C}_{\mathbf{4}}$ ( la mayoría de los pastos de estaciones cálidas). Estas y otras diferencias entre las especies podrían conducir a cambios en la composición de la vegetación en pastizales, pero es dificil hacer generalizaciones. En muchos pastizales, la abundancia de las especies está determinada más por atributos morfológicos y fenológicos que afectan el acceso de las plantas a recursos esenciales como nitrógeno y luz, y por reacciones al fuego, pastoreo y a otros factores disturbadores, que por mecanismos fisiológicos sencibles a la concentración de $\mathrm{CO}_{2}$. La composición de especies posiblemente será la de mayor repuesta a $\mathrm{CO}_{2}$ en ambientes con limitaciones moderadas de agua y en pasturas naturales intervenidas donde los múltiples efectos positivos de $\mathrm{CO}_{2}$ en las relaciones planta agua pueden expresarse y la competencia por luz es minima. Los mayores cambios en composición de especies posiblemente ocurrirán en pastizales con mezcla de especies $C_{3}$ y $C_{4}$, y en áreas de transición entre pastizales y bosques. La produccion de plantas en pastizales con limitaciones de agua debe también incrementar, pero el $\mathrm{CO}_{2}$ debe tener poca influencia en producción cuando se presentan limitaciones severas de nutrientes como nitrógeno.

Rangelands have been defined as areas that produce plants grazed by wild and domesticated animals (Stoddart et al. 1975). For this review, rangelands are defined as natural or seminatural herbaceous formations comprised mostly of grasses, with or without woody plants. Included in this definition of rangelands are grasslands, savannas, and shrub steppe, which together are the potential natural vegetation of about $25 \%$ of Earth's land surface (Lauenroth 1979). The characteristic that unites these ecosystems as rangelands is the production of grass.

It is thought that grasses evolved during the warm, moist Cretaceous Period 100 million years ago in seasonally or locally dry habitats (Upchurch and Wolfe 1987). Extensive grasslands apparently did not become widespread, however, until the mid- to late-Tertiary 5 to 15 million years ago (Smeins 1983, Thomas and Spicer 1987) when the climate became more arid. Further expansion and maintanence of grass-dominated communities has been linked to the influence of fire (Anderson 1982, Axelrod 1985) and, more recently, human activities in restricting woody encroachment.

Although aridity may have been necessary for grasses to expand, extensive areas of grass did not appear until after atmospheric carbon dioxide $\left(\mathrm{CO}_{2}\right)$ concentration declined. Atmospheric $\mathrm{CO}_{2}$ concentration declined abruptly at the end of the Cretaceous Period from perhaps as high as 3,000 ppm (parts per million) to near the current $360 \mathrm{ppm}$, and has remained relatively low to present (Fig. 1a; Lasaga et al. 1985, Berner 1990, 1992). During the last 200,000 years, $\mathrm{CO}_{2}$ concentration has fluctuated between about 200 and $270 \mathrm{ppm}$ between glaciation and interglacial periods (Fig. 1b; Barnola et al. 1987, Jouzel et al. 1993). Atmospheric $\mathrm{CO}_{2}$ rose near the end of glaciation about 10,000 years ago to the preindustrial level (c. $275 \mathrm{ppm})$ from a glacial $(-18,000$ years ago)

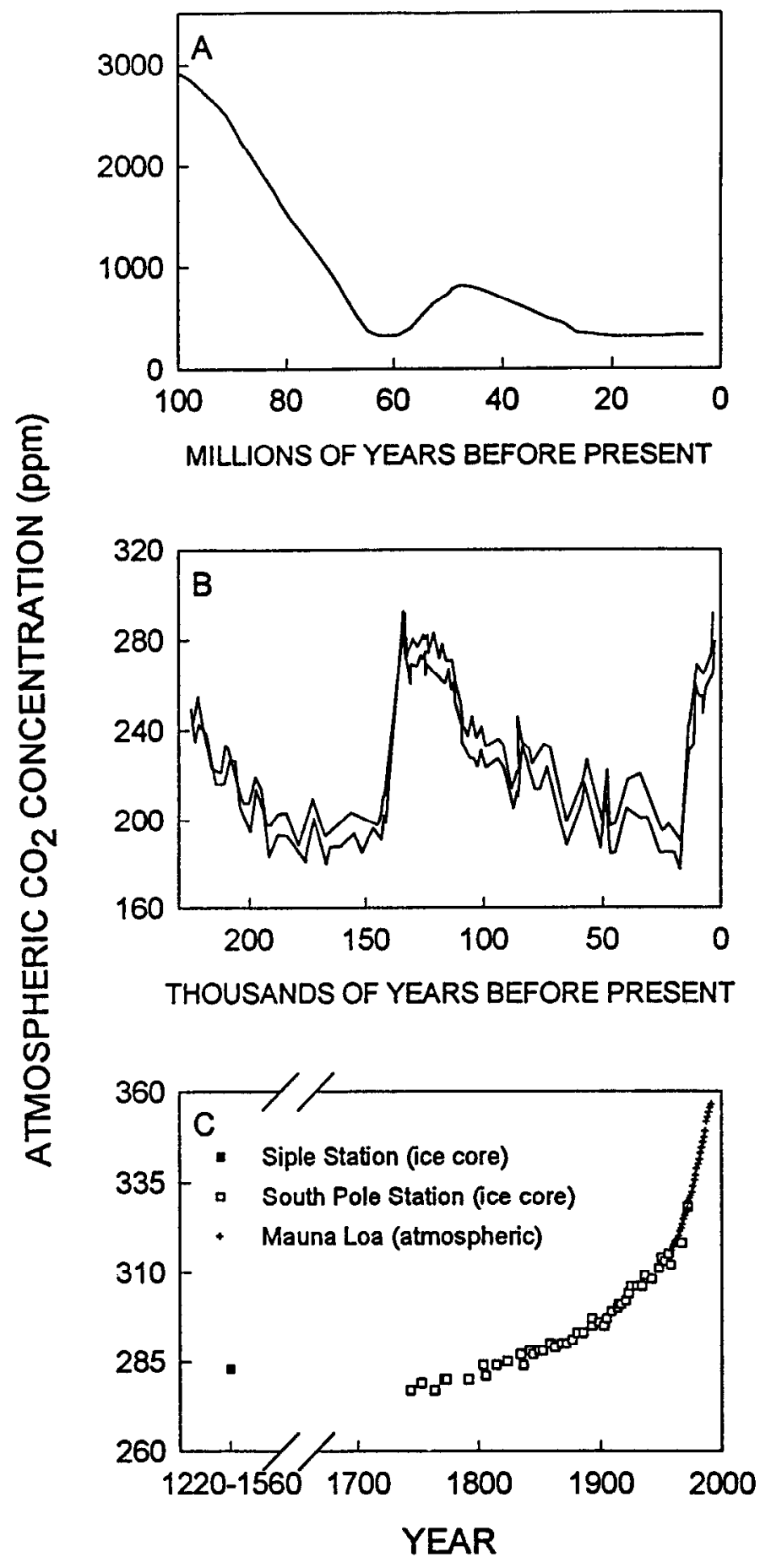

Fig. 1. Atmospheric $\mathrm{CO}_{2}$ concentration through time. (a) Atmospheric $\mathrm{CO}_{2}$ concentration during the last 100 million years as estimated with a geological carbon cycle model (Lasaga et al. 1985) and presented by Ehleringer et al. (1991). (b) The $\mathrm{CO}_{2}$ concentration of air trapped in ice of the Vostok core from Antarctica during the past 200,000 years. The envelope represents measurement accuracy. Figure was redrawn from Jouzel et al. (1993). (c) The $\mathrm{CO}_{2}$ concentration in air extracted from dated layers of ice cores from Siple and South Pole Stations, Antarctica and direct measurements of atmospheric $\mathrm{CO}_{2}$ concentration at Mauna Loa, Hawaii. Figure was redrawn from Friedli et al. (1986) and updated with data from Keeling and Whorf (1994). 
minimum ( 160 to $200 \mathrm{ppm}$, Delmas et al. 1980) that is among the lowest known $\mathrm{CO}_{2}$ concentrations in geological history (Bamola et al. 1987, Jouzel et al. 1993). During the last 200 years, fossil fuel burning and deforestation and other changes in land use have released more $\mathrm{CO}_{2}$ into the atmosphere than has been removed by diffusion into oceans or net uptake by plants. As a result, $\mathrm{CO}_{2}$ concentration has risen $30 \%$ to near 360 ppm (Fig. 1c; Keeling and Whorf 1994). Continued release of $\mathrm{CO}_{2}$ may swell the atmospheric concentration to twice its current level during the next century (Trabalka et al. 1986).

The role of $\mathrm{CO}_{2}$ change in the expansion of grasses and development of rangelands has largely been neglected until recently (Smith 1976, Ehleringer et al. 1991). There is now evidence that plants in which photosynthesis is relatively insensitive to low $\mathrm{CO}_{2}\left(\mathrm{C}_{4}\right.$ plants, like the grasses that dominate tropical grasslands) expanded after the atmospheric concentration declined (Cerling et al. 1993). Little attention, however, has been given to the influence that the sharp decline in $\mathrm{CO}_{2}$ concentration at the end of the Cretaceous likely had on the response of vegetation to increasing aridity and other climatic factors. Relationships of vegetation to the climate and other variables may now be changing as $\mathrm{CO}_{2}$ increases through concentrations unprecedented in the last 200,000 years or more (Barnola et al. 1987, Jouzel et al. 1993) to levels in the next century that are unmatched for at least the last several million years (Lasaga et al. 1985).

Here, I discuss implications of rising atmospheric $\mathrm{CO}_{2}$ concentration for rangelands. Because it is an essential plant resource, atmosphcric $\mathrm{CO}_{2}$ directly and indirectly influences a variety of plant properties that, in turn, may feed back to affect species composition and ecosystem processes. Following a review of impacts of atmospheric $\mathrm{CO}_{2}$ on plant physiology and growth, I will explore implications of rising $\mathrm{CO}_{2}$ for the productivity and species composition of rangeland plant communities. The effect of higher $\mathrm{CO}_{2}$ on plants often declines in moving from the leaf to plant and community levels, from short-term processes to those relevant at higher spatial and over longer temporal scales (Fig. 2). That theme will be evident. Low water or nutrient availabilities, in particular, often constrain plant production on rangelands. These same limitations can reduce absolute benefits of higher $\mathrm{CO}_{2}$ to rangeland vegetation. This point will also be emphasized throughout.

It should be recognized that most of the discussion at the plant community and ecosystem levels is necessarily speculative. Few $\mathrm{CO}_{2}$ studies have been conducted on grazing lands (apparently only 5) or other intact ecosystems. Studies that have been conducted were neither large enough nor continued long enough to fully accommodate species and genetic change, shifts in soil properties, and other changes that must be understood to predict $\mathrm{CO}_{2}$ effects on natural ecosystems.

\section{Plant Physiology}

\section{Photosynthesis}

Carbon dioxide is assimilated or fixed by the enzyme ribulose1,5-bisphosphate carboxylase/oxygenase (Rubisco) in leaf mesophyll cells of plants with the $C_{3}$ photosynthetic pathway. Included among $\mathrm{C}_{3}$ plants are virtually all trees and shrubs and most of the "cool-season" grasses of rangelands. Rubisco also reacts with the oxygen $\left(\mathrm{O}_{2}\right)$ in air, resulting in the loss of $\mathrm{CO}_{2}$ in a process called photorespiration. Under current atmospheric conditions and moderate leaf temperatures $\left(20-25^{\circ} \mathrm{C}\right), 30$ to $50 \%$ of the total amount of carbon (C) assimilated in $\mathrm{C}_{3}$ photosynthesis is lost to photorespiration (Long and Hutchin 1991). That propor-

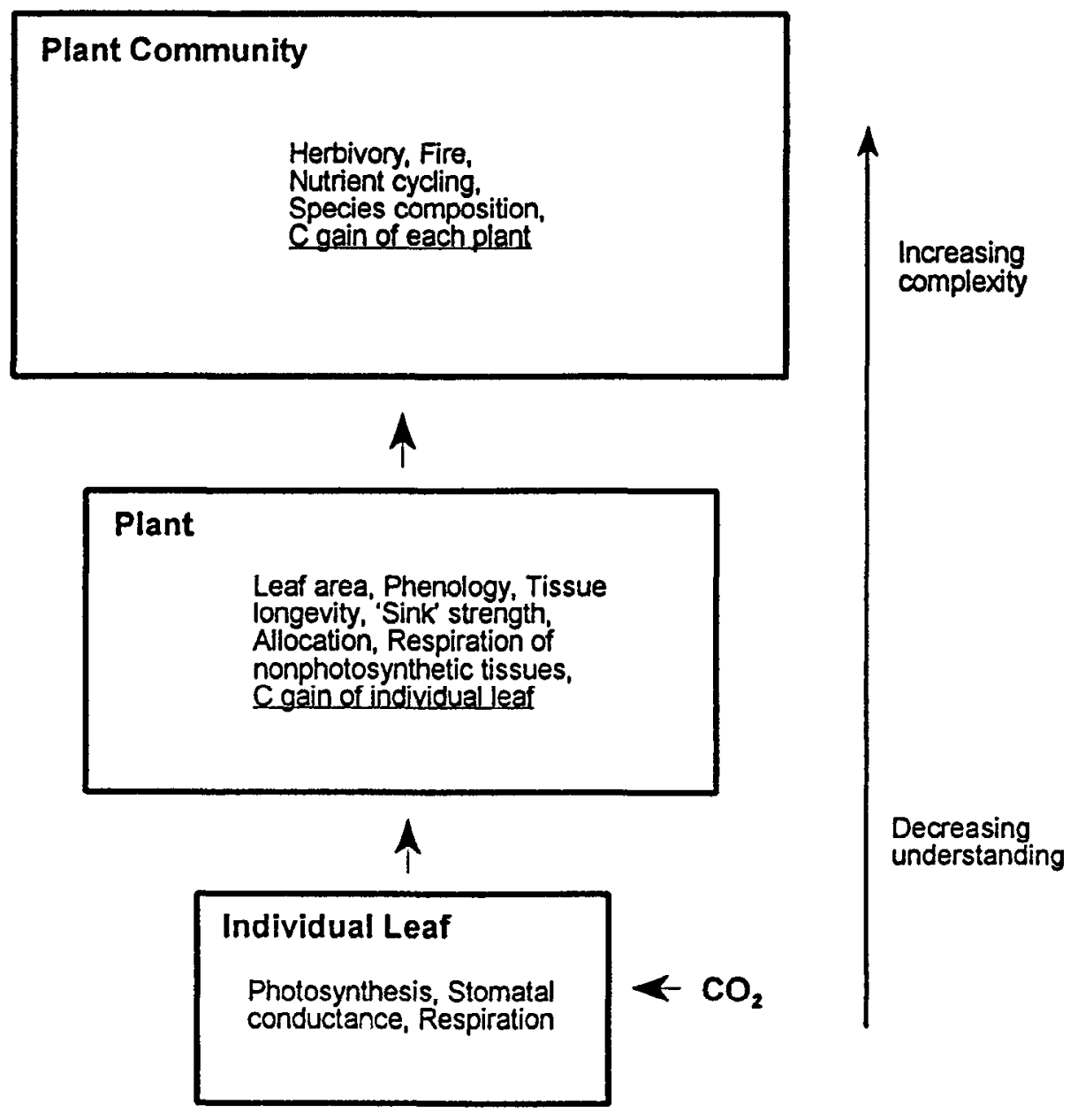

Fig. 2. Physiological and ecological factors influencing primary production (carbon gain) at each of 3 levels along a hierarchical gradient of increasing complexity, from the leaf to plant community. Carbon gain at each level is influenced by water and nutrient availabilities and environmental conditions like temperature. Effects of atmospheric $\mathrm{CO}_{2}$ concentration become imbedded in feed backs and increasingly less direct and well-understood as the temporal and spatial scales of interest are expanded. 
tion decreases sharply as $\mathrm{CO}_{2}$ concentration rises and temperature declines (Sharkey 1988, Ehleringer et al. 1991, Johnson et al. 1993). In plants with $C_{4}$ photosynthesis, including the grasses that dominate most warm-temperate and tropical grasslands, carboxylation by Rubisco occurs in leaf bundle sheath cells using $\mathrm{CO}_{2}$ that was initially assimilated by the enzyme phosphoenol pyruvate (PEP) carboxylase. Because PEP carboxylase does not react with $\mathrm{O}_{2}$, and $\mathrm{C}_{4}$ plants maintain high $\mathrm{CO}_{2}$ concentrations in bundle sheath cells, photorespiration is negligible in these species (Pearcy and Ehleringer 1984).

When measured at high light intensity, $\mathrm{C}_{3}$ net photosynthesis typically increases almost linearly to $\mathrm{CO}_{2}$ concentrations approaching the current level (Fig. 3; Long and Drake 1993), partly because photorespiration decreases. Beyond this phase of rapid increase, the additional $\mathrm{C}$ that is gained per unit of higher $\mathrm{CO}_{2}$ decreases progressively. Net photosynthesis is higher in $\mathrm{C}_{4}$ than $\mathrm{C}_{3}$ leaves at low $\mathrm{CO}_{2}$ concentrations, but $\mathrm{C}_{4}$ photosynthesis usually becomes $\mathrm{CO}_{2}$ saturated at comparably low concentrations (Fig. 3).

The photosynthetic advantage of $\mathrm{C}_{4}$ plants at low $\mathrm{CO}_{2}$ concentrations is achieved at the expense of an additional energy requirement. Because this energy comes from light, maximum photosynthesis per unit of absorbed light is lower in $\mathrm{C}_{4}$ plants than in $\mathrm{C}_{3}$ species in which photorespiration is inhibited by high $\mathrm{CO}_{2}$ concentration (Ehleringer and Björkman 1977). High $\mathrm{CO}_{2}$ thus places $\mathrm{C}_{4}$ plants at a disadvantage compared to $\mathrm{C}_{3}$ species when light limits growth.

Higher temperatures increase photorespiration in $\mathrm{C}_{3}$ plants. By reducing photorespiration, higher $\mathrm{CO}_{2}$ increases the temperature optimum for $\mathrm{CO}_{2}$ uptake and the maximum temperature at which positive photosynthesis can occur in $C_{3}$ species (Long 1991). Studies of both $\mathrm{C}_{3}$ photosynthesis and plant growth have demonstrated that plants usually respond relatively more to an increase in $\mathrm{CO}_{2}$ concentration when temperatures are high (e.g., Idso et al. 1987, Campbell et al. 1995; but see Morgan et al. 1994a).

\section{Respiration}

Carbon loss to processes involved in the growth and maintenance of plant tissues (respiration) is reduced by higher $\mathrm{CO}_{2}$ in some species, potentially further benefiting growth (Bunce 1990 , Amthor 1991). In some plants, $\mathrm{CO}_{2}$ directly inhibits respiration (Amthor et al. 1992). When plants are grown at elevated $\mathrm{CO}_{2}$, the inhibition may also include indirect effects that result when plant size, biomass distribution, and tissue composition are altered (Amthor 1991).

\section{Stomatal Conductance and Plant Water Relations}

Stomatal pores usually close as $\mathrm{CO}_{2}$ rises, thereby reducing stomatal (leaf) conductance to water vapor and leaf transpiration rate (Field et al. 1995). Morison (1987), in a review of studies on 25 species, found that conductance declined about $40 \%$ when leaves grown at the current $\mathrm{CO}_{2}$ concentration were exposed to near twice the ambient concentration. There were no consistent differences between $\mathrm{C}_{3}$ and $\mathrm{C}_{4}$ species.

Conductance is sometimes lower in leaves that have been grown at high $\mathrm{CO}_{2}$ than in those exposed for a short time to the elevated concentration (DeLucia et al. 1985, Spencer and Bowes 1986, Woodward 1987a, Berryman et al. 1994, Polley et al. 1997a). Mechanisms for this $\mathrm{CO}_{2}$ effect are not well-established. In some plants prolonged exposure to higher $\mathrm{CO}_{2}$ reduces the

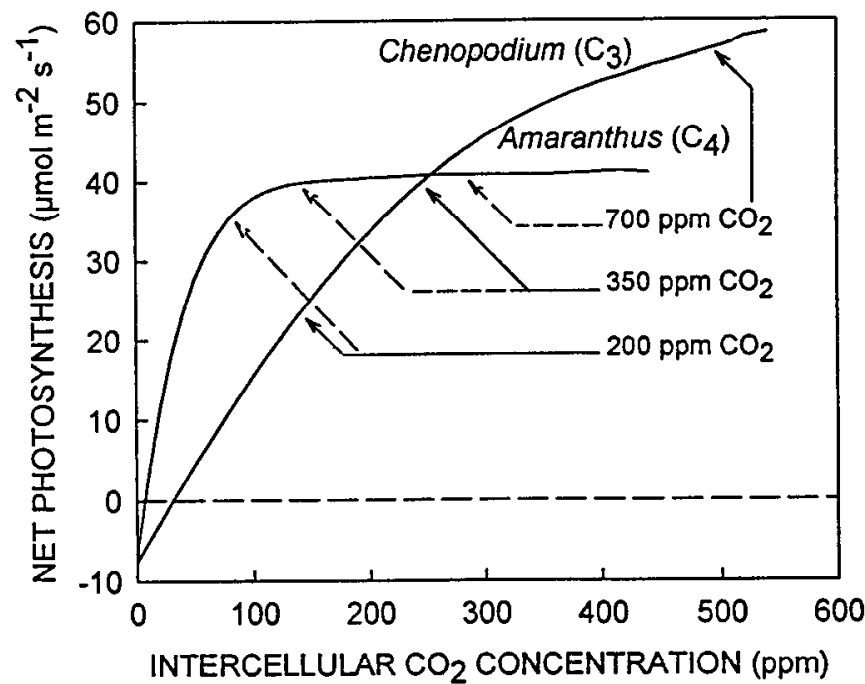

Fig. 3. Response of net photosynthesis of the $\mathrm{C}_{3}$ Chenopodium album and $\mathrm{C}_{4}$ Amaranthus retroflexus to leaf intercellular $\mathrm{CO}_{2}$ concentration $\left(c_{j}\right)$ (Pearcy and Ehleringer 1984). Arrows indicate photosynthesis and $c_{i}$ expected at atmospheric $\mathrm{CO}_{2}$ concentrations $\left(c_{\mathrm{a}}\right.$ ) of 200,350 , and $700 \mathrm{ppm}$ if the ratio of $c_{i}$ to $c_{\mathrm{a}}$ remains constant at 0.4 in the $C_{4}$ plant and 0.7 in the $C_{3}$ species and the photosynthetic response of each species to $c_{i}$ does not change with $c_{a}$

density of stomates on leaves (Woodward 1987a, Woodward and Bazzaz 1988, Jones et al. 1995), but this trend is far from universal (Rowland-Bamford et al. 1990, Malone et al. 1993, Knapp et al. 1994a, Morgan et al. 1994a). Stomatal response to $\mathrm{CO}_{2}$ generally may be better correlated with photosynthesis than with stomatal density (Morison 1987, Polley et al. 1993).

By reducing conductance, rising $\mathrm{CO}_{2}$ usually reduces leaf transpiration rate. The decline in transpiration rate rarely matches that in conductance, however. Low transpiration can lead to higher leaf temperatures and increase the temperature and decrease the humidity of air around and immediately above plant canopies. These feedbacks increase the rate of water loss at a given conductance (Morison and Gifford 1984, McNaughton and Jarvis 1991). When transpiration rates do decline, effects may include slower rates of soil water depletion by plants, improved plant water relations, higher water use efficiency (biomass production/transpiration, WUE), and greater production on rangelands and other water-limited ecosystems.

These improvements in water relations are often the primary benefits to plants in which photosynthesis is insensitive to $\mathrm{CO}_{2}$ (Owensby et al. 1993b). Doubling $\mathrm{CO}_{2}$ halved stomatal conductance of the dominant $\mathrm{C}_{4}$ species on tallgrass prairie in Kansas, U.S.A. (Kirkham et al. 1991, Knapp et al. 1994b) and reduced total evapotranspiration by 7 to $22 \%$ (Kirkham et al. 1991, Nie et al. 1992b, Ham et al. 1995). Soil water content (Kirkham et al. 1991, Owensby et al. 1993b) and midday plant water potentials in the prairie increased as a consequence (Knapp et al. 1993, Owensby et al. 1993b). Elevating $\mathrm{CO}_{2}$ had no consistent effect on leaf and canopy photosynthesis in the $\mathrm{C}_{4}$ prairie (Kirkham et al. 1991, Nie et al. 1992a, 1992b, Knapp et al. 1993), but increased biomass production during dry years by delaying the onset of drought (Fig. 4; Owensby et al. 1993b). 


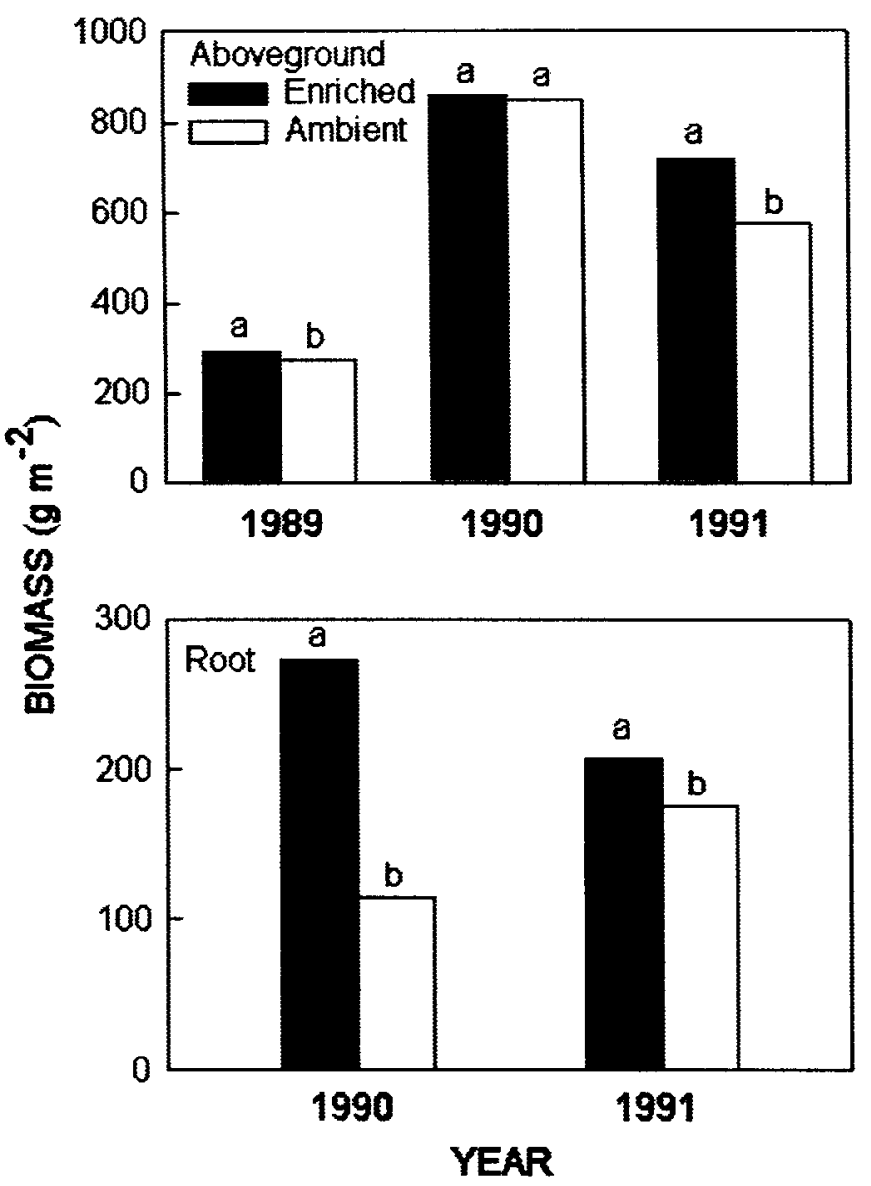

Fig. 4. Peak above-ground biomass (top) and root biomass to $15-\mathrm{cm}$ depth (bottom) in $\mathbf{C}_{4}$-dominated tallgrass prairie exposed to ambient and enriched (twice-ambient) $\mathrm{CO}_{2}$ concentrations. Total precipitation during 1989,1990 , and 1991 was $74 \%, 94 \%$, and $80 \%$ of the 30-year average, respectively. Means within a year differed significantly if headed by different letters. Figures were redrawn from Owensby et al. (1993b).

Partial stomatal closure is 1 mechanism by which $\mathrm{CO}_{2}$ enrichment ameliorates effects of drought and other environmental stresses. Another is by improving plant carbon balance (Sage 1996a). Additional carbohydrates can be used to increase osmotic adjustment and maintain turgor in water-stressed plants (Sionit et al. 1981, Morse et al. 1993, Eamus et al. 1995) and improve plant water balance or access to limiting soil nutrients by increasing root growth or the fraction of plant biomass invested in roots (Tolley and Strain 1985, Miao et al. 1992, Morgan et al. 1994b, Polley et al. 1994).

\section{Growth of Individual Plants}

There often is a strong correlation between the photosynthetic sensitivity and growth response of plants to $\mathrm{CO}_{2}$ when required resources like water, light, and $\mathrm{N}$ are readily available and plant densities are low. Increasing $\mathrm{CO}_{2}$ concentration, for instance, usually stimulates photosynthesis more in $C_{3}$ than $C_{4}$ species. The same is true of plant growth. Poorter (1993) found from a literature survey that doubling the current $\mathrm{CO}_{2}$ concentration increased growth by a mean $41 \%$ in $C_{3}$ species compared to $22 \%$ in $\mathrm{C}_{4}$ plants. It is also known that leaf photosynthesis of $\mathrm{C}_{3}$ plants is more responsive to $\mathrm{CO}_{2}$ over low concentrations representative of the past compared to elevated concentrations predicted for the future (Fig. 3). The same holds for plant $\mathrm{C}$ gain whether measured as growth or net photosynthesis of whole plants or plant stands (Fig. 5; Gifford 1977, Baker et al. 1990a, Allen et al. 1991, Dippery et al. 1995).

The correlation between physiological sensitivity and growth response to $\mathrm{CO}_{2}$ sometimes weakens when plant densities are high or environmental conditions are less than optimal, the very conditions that characterize many rangelands. Even when conditions are favorable for growth, the proportional increase in growth or production at higher $\mathrm{CO}_{2}$ is typically but a small fraction of the relative increase in leaf or canopy photosynthetic rates (Poorter 1993, Schäppi and Körner 1996). There are several reasons for these trends.

Growth and its response to $\mathrm{CO}_{2}$ are reduced when environmental conditions are unfavorable or resources are in short supply. Low temperature, for example, reduces the amount of additional growth that $\mathrm{C}_{3}$ forage species realize when $\mathrm{CO}_{2}$ is elevated (Campbell et al. 1995), and probably contributes to the minimal growth response of tussock tundra to higher $\mathrm{CO}_{2}$ (Oechel et al. 1994). Water and nutrients, particularly nitrogen (N), limit production on many temperate and tropical grasslands (Medina 1982, McNaughton et al. 1988, Seastedt et al. 1991) and limit the absolute growth response of plants to $\mathrm{CO}_{2}$ (Bazzaz 1990). Plants can compensate somewhat for nutritional limitations by decreasing tissue concentrations or reallocating elements from roots or other tissues to leaves and from processes that are no longer limiting to those that limit growth in the higher $\mathrm{CO}_{2}$ environment (Sage 1994, Polley et al. 1995). Plant nutrient use efficiency (biomass production per unit of nutrient element in the plant) may

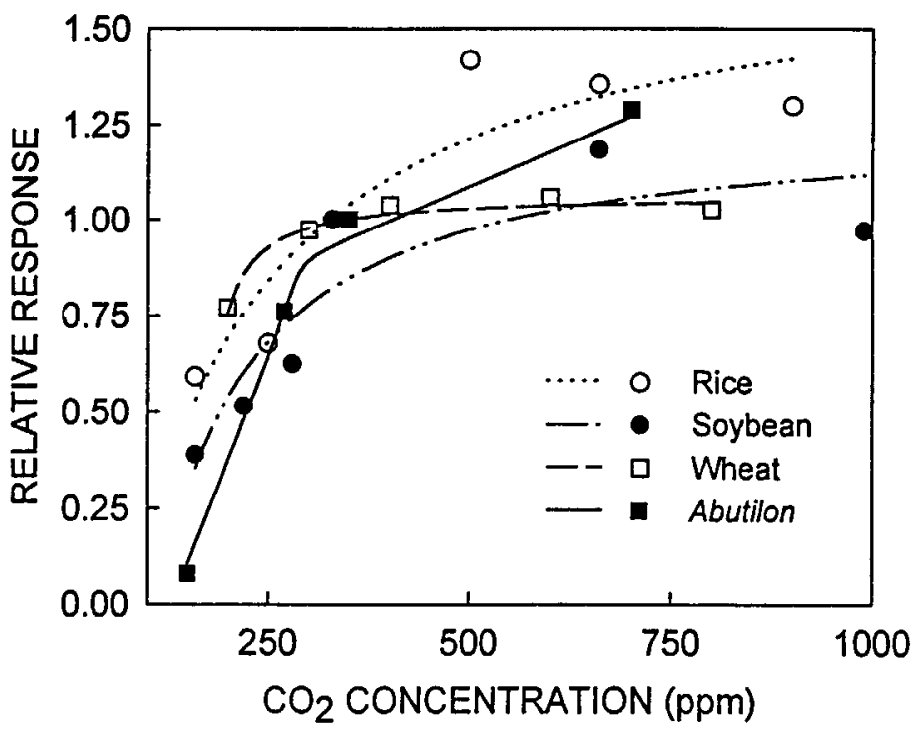

Fig. 5. Response of plant biomass to $\mathrm{CO}_{2}$ concentration, normalized to $330 \mathrm{ppm}$ (rice, soybean, wheat) or $350 \mathrm{ppm} \mathrm{CO}_{2}$ (Abutilon). Some plants of rice (Baker et al. 1990a) and soybean (Allen et al. 1991) were grown to maturity at $330 \mathrm{ppm} \mathrm{CO}_{2}$. The biomass of 24day-old wheat seedlings at $330 \mathrm{ppm} \mathrm{CO}_{2}$ was calculated from a rectangular hyperbola fit to the response of wheat biomass to $\mathrm{CO}_{2}$ levels from 200 to 800 ppm (Neales and Nicholls 1978). Some plants of Abutilon were grown for 35 days at $350 \mathrm{ppm} \mathrm{CO}_{2}$ (Dippery et al. 1995). 
increase as a result (Owensby et al. 1993a, Polley et al. 1995), and improve growth under nutrient stress. When production is low, as under nutrient or water limitation, even a small absolute increase in growth represents a large relative enhancement. Indeed, Idso and Idso (1994) concluded from a review of 10 years of research that $\mathrm{CO}_{2}$ enrichment can increase growth or photosynthesis relatively more when light, water, or nutrients are limiting than when these resources are abundant. The relative enhancement in plant response was greatest under water limitation, partly reflecting the increase in water use efficiency at high $\mathrm{CO}_{2}$. There was little or no increase in the relative response of nutrient-limited plants until the $\mathrm{CO}_{2}$ concentration exceeded that expected during the next century.

Factors internal to plants, like $\mathrm{C}$ allocation patterns and loss rates and constraints on the rate at which $\mathrm{C}$ can be stored, further affect growth responses to $\mathrm{CO}_{2}$ (Fig. 2). When compared at a given $\mathrm{CO}_{2}$ concentration, leaf photosynthesis is sometimes lower in plants that have been grown at elevated $\mathrm{CO}_{2}$ than the current concentration (DeLucia et al. 1985, Sage et al. 1989, Morgan et al. 1994a, Polley et al. 1997a). This 'down-regulation' or adjustment of photosynthetic capacity usually reduces, but does not eliminate, the positive effect of higher $\mathrm{CO}_{2}$ on $\mathrm{C}$ gain (Morgan et al. 1994a). Down-regulation of photosynthesis could be beneficial if resources committed to structures or processes that no longer limit $\mathrm{C}$ fixation are used to improve physiological performance in the new $\mathrm{CO}_{2}$ environment. Such changes are not common, however (Sage 1994). Photosynthetic inhibition is often associated with excessive accumulation of carbohydrates in leaves that either physically disrupt chloroplasts or feed back to reduce the synthesis of photosynthetic enzymes (Stitt 1991). The inability of plants to export or use these extra carbohydrates can often be traced directly or indirectly to nutritional limitations or insufficient carbohydrate (assimilate) sinks in plants (Stitt 1991, Sage 1994). "Sink strength" and plant growth response to $\mathrm{CO}_{2}$ are high during reproductive phases of growth, when rooting volume and $\mathrm{N}$ availability do not limit tissue development, and in legumes with $\mathrm{N}_{2}$-fixing nodules.

Plant productivity is a function of both the ratio and magnitudes of processes that promote $C$ gain and those, like senescence (turnover), that reduce the amount of $\mathrm{C}$ that can be reinvested in further growth. Atmospheric $\mathrm{CO}_{2}$ probably does not affect tissue senescence directly, but acts by altering plant nutrition or water status and rates of growth and development. Higher $\mathrm{CO}_{2}$ may accelerate plant development and leaf initiation rates (Cure et al. 1989, Baker et al. 1990b) and thereby cause leaves to senesce earlier in some species (St. Omer and Horvath 1983, McConnaughay et al. 1996), but these effects are sensitive to temperature (Coleman et al. 1991, Ackerly et al. 1992). In other species and ecosystems, increasing $\mathrm{CO}_{2}$ concentration reduces rates of leaf senescence (Curtis et al. 1989, Polley et al. 1992) or delays the onset of dormancy (Grulke et al. 1990).

Plants that grow rapidly usually invest a high percentage of fixed $\mathrm{C}$ or total biomass into the means for acquiring still more $\mathrm{C}$, additional leaf area (Mooney 1972, Poorter and Remkes 1990). In some plants, however, the increased supply of photosynthate at high $\mathrm{CO}_{2}$ is accumulated as starch, rather than invested in new leaves or other tissues (Poorter 1993). Further, leaf area per unit of plant biomass (the ratio of photosynthetic surface to mass of respiring tissue) usually declines at high $\mathrm{CO}_{2}$. Leaves typically are heavier per unit area when grown at elevated $\mathrm{CO}_{2}$ concentra- tion (Jackson et al. 1995 ) partly, at least, because of carbohydrate accumulation (Körner and Miglietta 1994). Root growth and the fraction of plant biomass in roots also commonly increase (Rogers et al. 1994), thereby decreasing the ratio of leaf area or shoot biomass to plant biomass (Polley et al. 1994, Jongen et al. 1995). But, there is considerable variation in the response of root:shoot ratios to $\mathrm{CO}_{2}$ (Rogers et al. 1994). Carbon dioxide enrichment increased the ratio of root biomass to shoot biomass in the annual grass Bromus mollis (Larigauderie et al. 1988), for example, but did not affect this variable in 2 perennial grasses from the shortgrass steppe (Hunt et al. 1996). When biomass distribution patterns do change, it often is not clear whether the modification reflects $\mathrm{CO}_{2}$-induced shifts in $\mathrm{C}$ partitioning or merely results from changes in plant growth rates or soil nutrient and water levels. As plants grow, they often invest relatively more biomass in structural or support tissues like roots. In some cases, therefore, plants have higher ratios of root biomass to shoot biomass at elevated $\mathrm{CO}_{2}$ simply because they are larger. The few studies that have compared root and shoot fractions among plants of similar size indicate that $\mathrm{CO}_{2}$ concentration does not consistently affect $\mathrm{C}$ distribution patterns (Farrar and Williams 1991, Tischler et al. 1996). Plants alter partitioning to compensate for resource imbalances (Brouwer 1983). Shoots become relatively larger when light is limiting, for example. Conversely, relative investment of biomass in roots increases when nutrients and water become limiting, as may occur when $\mathrm{CO}_{2}$ enrichment stimulates plant growth and uptake of these resources.

\section{Rangeland Plant Communities}

\section{Primary Production}

Observed Responses. Effects of $\mathrm{CO}_{2}$ on production of plant stands can usually be inferred from our knowledge of physiological and whole-plant responses to $\mathrm{CO}_{2}$. Consistent with trends observed on individual plants, many natural ecosystems, including some grasslands, show little or no increase in standing crop or production at higher $\mathrm{CO}_{2}$ when temperatures are low or nutrients are limiting (Oechel et al. 1994, Fredeen et al. 1995, Schäppi and Körner 1996). Although atmospheric $\mathrm{CO}_{2}$ concentration clearly was suboptimal for maximal $\mathrm{C}_{3}$ growth during the past (Polley et al. 1992, Dippery et al. 1995), Jenkinson et al. (1994) found no relationship between atmospheric $\mathrm{CO}_{2}$ and herbage yields during the last century in the Park Grass Experiment in Great Britain. Low temperatures or nutrient levels apparently limited production.

By contrast, $\mathrm{CO}_{2}$ enrichment consistently increases production when essential nutrient elements like $\mathbf{N}$ are plentiful or water begins to limit growth and positive effects of $\mathrm{CO}_{2}$ on water relations are expressed. Elevating $\mathrm{CO}_{2}$ increased above-ground production (Curtis et al. 1989) and root growth of the $C_{3}$ Scirpus olneyi in pure stands and mixed communities with the $\mathrm{C}_{4}$ species Spartina patens (Ait.) Muhl.and Distichlis spicata on nutrientrich coastal salt marsh on Chesapeake Bay (Curtis et al. 1990). Growth of $\mathrm{C}_{4}$ species was not affected by $\mathrm{CO}_{2}$ in this wet environment (Curtis et al. 1989, Arp et al. 1993) or in tallgrass prairie during wet years (Owensby et al. 1993b). Elevating $\mathrm{CO}_{2}$ did increase production in the $\mathrm{C}_{4}$-dominated prairie during dry years, however (Fig. 4; Owensby et al. 1993b). By reducing evapotran- 
spiration (Kirkham et al. 1991, Nie et al. 1992b, Ham et al. 1995) and soil water depletion (Kirkham et al. 1991, Owensby et al. 1993b), higher $\mathrm{CO}_{2}$ delayed late-season senescence in the perennial tallgrasses (Ham et al. 1995) and protected photosynthetic processes during drought (Knapp et al. 1993). Doubling $\mathrm{CO}_{2}$ concentration also increased production of perennial grasses from shortgrass steppe (Hunt et al. 1996). Production of a $C_{3}$ and a $C_{4}$ grass increased by a mean $19 \%$ at high $\mathrm{CO}_{2}$ when irrigated to simulate precipitation in this water-limited grassland.

Limitations of Field Studies. Field experiments with $\mathrm{CO}_{2}$ obviously provide the most direct evidence for likely effects of atmospheric change on production of rangelands and other ecosystems. The cost of exposing field vegetation to different $\mathrm{CO}_{2}$ concentrations, however, limits the soil surface area and number of plants that can be studied. Consequently, growth in $\mathrm{CO}_{2}$-enriched plots is usually estimated from small samples of vegetation collected a few times (sometimes only once) per year. Such infrequent sampling clearly does not provide a rigorous measure of primary production (Amthor 1995).

It is possible then that higher $\mathrm{CO}_{2}$ stimulates production more frequently than reported, but that existing sampling methods simply are not extensive or intensive enough to detect the increase. Litter accumulation increases dramatically in some systems as $\mathrm{CO}_{2}$ rises, even when there is no accompanying change in standing crop of live tissue (Navas et al. 1995). One implication is that net primary production also increased (although decomposition rates could also have slowed). Root production on grassland is usually underestimated because root turnover is not adequately measured (Long et al. 1989). Elevating $\mathrm{CO}_{2}$ increases root biomass on grasslands with some consistency (Fig. 4; Owensby et al. 1993b, 1994, Newton et al. 1995, Jongen et al. 1995). The increase in root production may be even greater, if turnover per unit of measured root biomass does not decline at high $\mathrm{CO}_{2}$. Several researchers have observed that $\mathrm{CO}_{2}$ efflux rates from soil ("soil" respiration) increase in plots exposed to elevated $\mathrm{CO}_{2}$ (Newton et al. 1995, Luo et al. 1996; but see Jongen et al. 1995), suggesting that $\mathrm{CO}_{2}$ stimulated root turnover. A variety of factors other than decomposition of newly-produced root litter may contribute to these trends, however. Included are respiration from active roots and decomposition rates of $\mathrm{C}$-rich root exudates and native soil organic matter.

Perhaps the best evidence that $\mathrm{CO}_{2}$ usually stimulates production comes from measurements of $\mathrm{CO}_{2}$ fluxes over plant stands. Increasing $\mathrm{CO}_{2}$ increases canopy photosynthetic rate or net ecosystem $\mathrm{CO}_{2}$ uptake (net photosynthesis minus soil plus plant respiration) in almost all experiments, at least temporarily (Grulke et al. 1990, Drake and Leadley 1991, Diemer 1994, Fredeen et al. 1995, Ham et al. 1995). Sometimes, the increase in $\mathrm{CO}_{2}$ uptake is greater than can be accounted for by an increase in plant biomass (Fredeen et al. 1995, Schäppi and Körner 1996), suggesting that $\mathbf{C}$ is being stored or sequestered in soil. The extra $C$ could result from an increase in the mass of senescent roots or increased $\mathrm{C}$ exudation, components of production that are difficult to quantify. Alternatively, it could reflect changes not directly related to production, like slower decomposition of native soil organic matter.

Long-Term Controls on Production-Grazers. Grazers strongly influence plant productivity on rangelands, but few investigators have examined interactions between $\mathrm{CO}_{2}$ concentration and plant response to defoliation. Tolerance to defoliation often is associated with the ability to rapidly replace photosyn- thetic tissues and recover pre-defoliation levels of plant $\mathbf{C}$ gain (Caldwell et al. 1981, Briske 1991). At least in $C_{3}$ plants, we might expect that $\mathrm{CO}_{2}$ enrichment would speed plant recovery from defoliation by stimulating photosynthesis. That expectation has not been supported by the few studies to date. Compensation for defoliation was no greater at high than the present $\mathrm{CO}_{2}$ concentration in a $\mathrm{C}_{3}$ forb [(Plantago lanceolata L.; Fajer et al. (1991)] or a $\mathrm{C}_{4}$ grass [(Sporobolus kentrophyllus; Wilsey et al. (1994)].

Individual animal productivity may also be affected by higher $\mathrm{CO}_{2}$ concentration if plant nitrogen concentration declines as often observed (e.g., Owensby et al. 1993a). Microbes drive digestion in ruminants (e.g., cattle, sheep, goats). When forage quality is poor, the rate of digestion and intake of plant material is reduced. Without dietary supplementation, growth and reproduction of individual animals could decrease as $\mathrm{CO}_{2}$ concentration rises (Owensby et al. 1996).

Long-Term Controls on Production-Species Change. A consequence of practical limits on the size and duration of $\mathrm{CO}_{2}$ field experiments is that effects of plant species change and shifts in genetic frequencies within species on plant productivity are difficult to estimate (Campbell et al. 1995). A shift to species or genotypes better adapted to higher $\mathrm{CO}_{2}$ could increase productivity above that anticipated from the response of existing vegetation. Bolker et al. (1995) used a mathematical model to study the response of productivity in a temperate forest over a period of 50 to 150 years to a doubling of $\mathrm{CO}_{2}$ concentration. Effects of species diversity were assessed by comparing the simulated increase in basal area of trees in a forest with a constant species composition and uniform sensitivity to $\mathrm{CO}_{2}$ to that in a forest in which species responded differently to $\mathrm{CO}_{2}$. Simulations that incorporated species-specific responses to $\mathrm{CO}_{2}$ and allowed species change yielded about a $30 \%$ increase in basal area over those that held species composition constant as $\mathrm{CO}_{2}$ concentration increased.

Long-Term Controls on Production-Nitrogen Availability. Low $\mathbf{N}$ availability is a common constraint on rangeland production (Medina 1982, McNaughton et al. 1988, Seastedt et al. 1991). There is evidence from several growth chamber experiments (Wong 1979, Lariagurarie et al. 1988) and an increasing number of field studies (Owensby et al. 1994, Schäppi and Körner 1996) that low soil $\mathrm{N}$ limits plant growth responses to higher $\mathrm{CO}_{2}$. Results from most of these studies, however, depended on the biologically-available $\mathrm{N}$ initially in the system studied. Account was not given to longer-term processes that influence $\mathrm{N}$ availability, including species change, abiotic input or loss of $\mathrm{N}$, and biological fixation of $\mathrm{N}$ from the poorly-exploited atmospheric reservoir (Table 1).

Most of the $\mathrm{N}$ available to plants on rangelands comes from microbial release (mineralization) from plant litter and soil organic matter. Nitrogen mineralization depends, in turn, on total organic $\mathbf{N}$ and factors like soil abiotic conditions and the chemical composition of organic matter that regulate the activities of decomposers.

Several have suggested that litter produced at progressively higher $\mathrm{CO}_{2}$ concentration will be $\mathrm{N}$ poor and contain greater amounts of recalcitrant compounds, like lignin. Since microorganisms require $\mathbf{N}$, as well as $\mathrm{C}$, they immobilize inorganic $\mathbf{N}$ during decomposition of $\mathrm{N}$-poor litter. Decomposition and $\mathrm{N}$ mineralization could decline as a result and initiate a negative feedback on $\mathrm{N}$ availability that reduces plant growth (Díaz et al. 
1993). Doubling $\mathrm{CO}_{2}$ reduced the nitrogen concentration in senescent shoots of grasses from shortgrass steppe (Hunt et al. 1996). There is evidence that grass roots produced at twice the present $\mathrm{CO}_{2}$ concentration decompose more slowly than those grown at today's $\mathrm{CO}_{2}$ level (Gorissen et al. 1995). Total $\mathrm{N}$ uptake of the $\mathrm{C}_{4}$ grass blue grama (Bouteloua gracilis (H.B.K.) Griffiths) and soil solution $\mathrm{NO}_{3}{ }^{-}$levels were reduced at $700 \mathrm{ppm}$ relative to $350 \mathrm{ppm}$ (Morgan et al. 1994b), also suggesting a negative feedback of elevated $\mathrm{CO}_{2}$ on $\mathrm{N}$ mineralization and availability to plants.

The weight of evidence, however, does not support a negative feedback by higher $\mathrm{CO}_{2}$ concentration on decomposition and $\mathrm{N}$ mineralization. In their review, O'Neill and Norby (1996) concluded that decomposibility of naturally abscissed leaf litter from plants grown in the field was not greatly affected by the $\mathrm{CO}_{2}$ concentration at which litter was produced. Indeed, growth $\mathrm{CO}_{2}$ concentration had little effect on decomposition of standing dead material from 3 tallgrass prairie species (Kemp et al. 1994). Others have argued that increased $\mathrm{C}$ input to soil may actually stimulate the recycling of $\mathrm{N}$ through microbes (Zak et al. 1993). Hunt et al. (1991) used a simulation model to show that $\mathrm{N}$ cycling rates could increase and partly offset the $\mathrm{N}$ limitation that resulted from greater production of both the $\mathrm{C}_{3}$ crested wheatgrass (Agropyron cristatum (L.) Gaertn.) and $\mathrm{C}_{4}$ blue grama as $\mathrm{CO}_{2}$ rises.

Across ecosystems, abiotic factors like soil water content and temperature may be better predictors of decomposition rate than substrate quality alone (Hunt 1977, Hunt et al. 1988, Parton et al. 1987). Schimel et al. (1990) demonstrated that the higher temperatures expected as a result of increasing $\mathrm{CO}_{2}$ concentration should speed decomposition of soil organic matter and the accompanying mineralization of $\mathrm{N}$ in grasslands in the central U.S. Soil organic matter dynamics, like plant production, should also be sensitive to changes in soil moisture, mediated directly by altered precipitation or indirectly via $\mathrm{CO}_{2}$ concentration. In systems where species composition or low $\mathrm{N}$ availability limit the amount of extra growth expected from additional $\mathrm{CO}_{2}$, water saved as a result of lower transpiration may accumulate in soil (Kirkham et al. 1991) and stimulate microbial activity (Rice et al. 1994).

Over decades and centuries, it is the balance of $\mathbf{N}$ inputs and losses and the partitioning of $\mathrm{N}$ among rapidly and slowly mineralizable pools in soil organic matter that dictate $\mathbf{N}$ availability to plants. Nitrogen is added to unmanaged rangelands by organisms capable of reducing atmospheric $\mathrm{N}_{2}$ to ammonia ( $\mathrm{N}_{2}$-fixation) and as wet and dry deposition from the atmosphere. Rising $\mathrm{CO}_{2}$ may increase $\mathrm{N}$ input to rangelands by directly or indirectly promoting $\mathrm{N}_{2}$-fixation, at least where nutrients other than $\mathrm{N}$ are not limiting (Table 1; Eisele et al. 1989, Ritchie and Tilman 1995). Herbaceous legumes are infrequent on many grasslands, apparently because they are preferred by herbivores or limited by water or nutrients other than N (Ritchie and Tilman 1995). Some of the more successful woody invaders of grasslands (including species of the genera Prosopis and Acacia), however, are also legumes. Symbiotic fixation in these species can be stimulated by higher $\mathrm{CO}_{2}$ concentration, in some cases dramatically. Plants of the woody legume huisache (Acacia smallii Isely), for example, derived 3 to 4 times more $\mathrm{N}$ from fixation when grown for a year at elevated $\mathrm{CO}_{2}$ than the current concentration (Polley et al. 1997a). Nitrogen fixation in another grassland invader, mesquite (Prosopis glandulosa Torr.), increased from near zero at the preindustrial $\mathrm{CO}_{2}$ level to $46 \%$ of plant $\mathrm{N}$ at the current concentration (Polley et al. 1994). By adding fixed $\mathrm{N}$ to rangelands in litterfall and root turnover, these woody invaders could increase potential productivity and its response to $\mathrm{CO}_{2}$ if $\mathrm{N}$ gains are not offset by losses or the conversion of $\mathrm{N}$ to recalcitrant forms.

Aber et al. (1991) concluded from a simulation study of $\mathrm{N}$ cycling in temperate forests that as long as $\mathrm{N}$ inputs exceed losses there theoretically is no limit to the amount of $\mathrm{N}$ that may be retained and cycled in the absence of other limitations on plant growth. That $\mathrm{N}$ availability on many rangelands is limiting implies that events like fire prevent $\mathrm{N}$ sequestration or that other factors constrain plant production or $\mathrm{N}$ inputs. Increasing $\mathrm{CO}_{2}$ concentration should lessen limitations imposed on plant growth by water by increasing water use efficiency. It may be that $\mathrm{N}$ cycling will increase with $\mathrm{CO}_{2}$ to the limit imposed by the higher resource use efficiency or until other factors become limiting.

Rates of $\mathbf{N}$ input, litter quality, and the frequency of events like fire that promote substantial $\mathbf{N}$ loss, all mediate how quickly $\mathbf{N}$ accumulation and cycling approach the maximum possible at a given $\mathrm{CO}_{2}$ concentration (Aber et al. 1991). Where the net $\mathrm{N}$ balance is positive, the ultimate limit to $\mathrm{N}$ cycling is imposed by the pool of potential species and their resource requirements relative to availabilities. Potential production on many rangelands may, therefore, be constrained by management practices that promote $\mathrm{N}$ loss or preclude $\mathrm{N}$ accumulation by limiting species change. Changes in species distributions and abundances lagged behind past shifts in climate, often by several decades or centuries (Davis 1986), so it is likely that the inertia of present species composition will at least initially constrain production in N-limited grasslands as $\mathrm{CO}_{2}$ rises at an accelerated rate through the next century. Lags in species change and $\mathrm{N}$ accumulation presumably imposed fewer limits on plant response to $\mathrm{CO}_{2}$ in the past when concentrations rose more slowly and with greater relaxation time between changes than today.

\section{Species Change}

General Considerations. Our ability to anticipate species change or even to define the role of atmospheric change in vegetation dynamics of the past is very limited. On rangelands, like other ecosystems, species change is a directional process that occurs when there is a shift in the relative abundances of existing species or new species proliferate. This differs from the year-to-

Table 1. Three components of the nitrogen $(N)$ cycle on rangelands that may be affected by atmospheric $\mathrm{CO}_{2}$ concentration. Rising $\mathrm{CO}_{2}$ may increase $(+)$ or decrease $(-)$ each component of the $N$ cycle by influencing listed factors and processes.

\begin{tabular}{lcc}
\hline \hline $\mathrm{N}$ mineralization rate & $\mathrm{N}$ input & $\mathrm{N}$ losses \\
\hline- ? Litter quality $(\mathrm{C} / \mathrm{N})$ & $+\mathrm{N}_{2}$ fixation & + Gaseous emissions \\
& & (correlated with production and $\mathrm{N}$ turnover rates) \\
+ Litter quantity & & + Volatilization during fire \\
+ Soil water content & (increase in fire frequency) \\
\hline
\end{tabular}


year variability in species abundances that is common on many grasslands and other rangelands (e.g., Tilman 1996).

Pickett et al. (1987) identified 3 general causes of succession or species change: site availability, differential species availability, and differential species performance (Fig. 6). First, sites must be available for colonization (site availability), especially when invading or expanding species establish from seed. Secondly, propagules of expanding species must be available (species availability). Existing species may spread vegetatively. For most invading species, seed must be dispersed onto new sites. Thirdly, species must perform differently at a site (species performance). Because of superior growth, reproduction, competitive ability, or tolerance to abiotic or biotic stresses, some species must eventually be 'favored' over others. If $\mathrm{CO}_{2}$ concentration is to affect species composition, it must influence at least 1 of these conditions.

Atmospheric $\mathrm{CO}_{2}$ does not, of course, directly affect propagule dispersal or create sites for colonization. It can, however, affect the production of seed and other propagules and may indirectly alter some of the disturbances that open sites for colonization. Atmospheric $\mathrm{CO}_{2}$ most directly affects plant performance, but so do several other factors including the availability of essential plant resources, levels of nonresource factors like temperature, and the frequency and intensity of disturbances like grazing and severe droughts (Fig. 6). Carbon dioxide concentration and these other factors interact with plant physiology, growth form, and life-history characteristics to influence plant-plant interactions. We should expect, therefore, that the primary mechanism by which $\mathrm{CO}_{2}$ influences vegetation and the relative importance of $\mathrm{CO}_{2}$ to species dynamics will vary as other factors change.

Site Availability. Colonization sites are created when existing plants die or disturbances remove the canopy or litter or disturb the soil surface. One of the disturbances that creates colonization sites on grasslands is fire. In the absence of fire, litter often accumulates. The accumulation of litter, together with other changes on unburned rangeland, can inhibit germination (Kitajima and Tilman 1996) and, possibly, seedling survival and contribute to a decline in plant species diversity (Tilman 1993).

Through its effects on plants, rising $\mathrm{CO}_{2}$ concentration could modify 3 characteristics that influence fire frequency and intensity: fuel load, fuel chemistry, and fuel water content (Sage 1996b). Fuel load is highly correlated with biomass production and turnover. In systems in which $\mathrm{CO}_{2}$ enrichment increases production, the rate and extent of fuel accumulation should also increase. Fires may burn more frequently or with greater intensity.
Flammability is influenced by tissue chemistry. One of the frequent changes in tissue chemistry at elevated $\mathrm{CO}_{2}$ is accumulation of non-structural carbohydrates (Körner and Miglietta 1994), which could increase flammability (Sage 1996b). Alternatively, $\mathrm{CO}_{2}$ enrichment may increase fire frequencies or intensities by promoting expansion of species, like cheatgrass (Bromus tectorum L.), with highly flammable litter (Smith et al. 1987). These positive effects of $\mathrm{CO}_{2}$ on fire could be offset to some extent by an increase in the water potential of live vegetation (Knapp et al. 1993, Owensby et al. 1993b, Jackson et al. 1994). The intensity, temperature, and rate of spread of fire decline as the moisture content of fuel rises (Sage 1996b). Carbon dioxide enrichment has been found to delay the onset of drought-induced senescence on grasslands (Ham et al. 1995), thus potentially constricting the period of greatest fire danger. Effects of severe drought are

\section{General Requirements for Plant Species Change}

1. Sites are available for colonization Disturbances (fire, trampling by animals, severe drought)

\section{Species are differentially available Pool of seed and other propagules Seed dispersal}

3. Species perform differently at a site Plant characteristics affecting performance - Morphology

- Physiology

- Life history

Biotic and abiotic factors affecting performance

- Disturbances (fire, herbivory)

- Resource availability (water, N)

- Climatic conditions (temperature)

- Plant-plant interactions

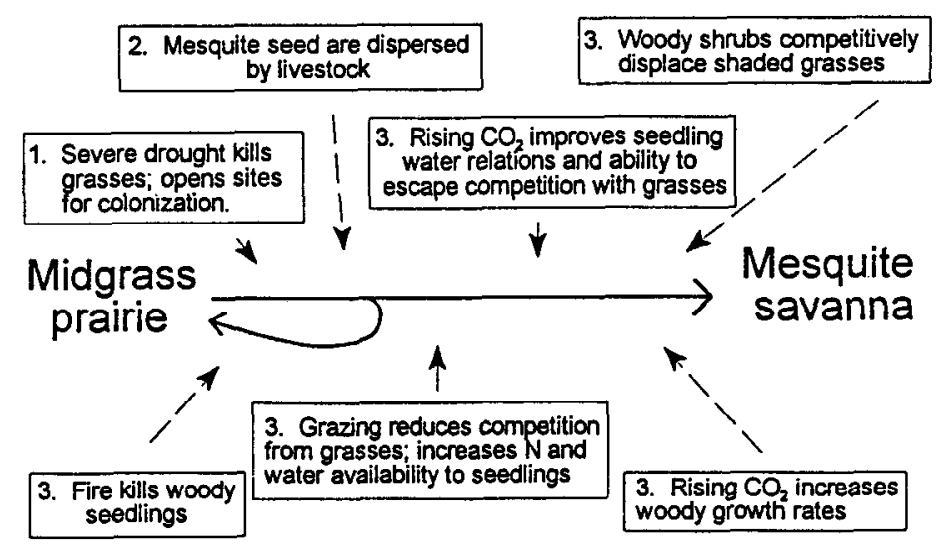

Fig. 6. (top) The 3 general requirements for plant species change and some of the processes or conditions that contribute to each requirement (adapted from Pickett et al. 1987). Rising atmospheric $\mathrm{CO}_{2}$ concentration may affect the production of seeds and other propagules (2) and indirectly influence certain disturbances (1), but most directly influences plant species abundances and distributions by altering plant performance (3). (bottom) A model of vegetation change from midgrass prairie to mesquite (Prosopis) savanna that illustrates mechanisms by which the requirements for species change may be satisfied. Mechanisms are shown in boxes and are numbered (as above) to correspond with the requirement for change to which they apply. Dashed lines indicate the point of action of each mechanism along a temporal sequence (solid line) from open grassland to savanna during invasion by mesquite. 
delayed by only a few days or weeks in most $\mathrm{CO}_{2}$ studies, so it is not likely that the probability of fire will decline significantly except on relatively mesic grasslands with short drought periods.

Species Availability. In the absence of continued immigration, invading plant populations will persist only if they reproduce and their offspring establish. The most successful species and genotypes within species may well be those in which reproduction and fitness respond most to rising $\mathrm{CO}_{2}$. Responses of reproduction and fitness to $\mathrm{CO}_{2}$ differed among 3 annual species studied by Farnsworth and Bazzaz (1995). Both, however, were poorly correlated with early vegetative growth. When reproduction is coupled more closely to population-level phenomena than physiological parameters, effects of $\mathrm{CO}_{2}$ may even be counterintuitive. Seed production of wild oat (Avena burbata Brot.), the dominant species in annual grassland in California, increased much more at elevated $\mathrm{CO}_{2}$ during a dry than relatively wet year (Jackson et al. 1995). Doubling $\mathrm{CO}_{2}$ concentration doubled the density and total seed production of wild oat plants during the dry year, apparently by increasing seedling establishment and survivorship.

Species Performance. Effects of $\mathrm{CO}_{2}$ concentration on species dynamics have been investigated extensively, mostly using artificial mixtures of plants. While much has been learned from these studies, perhaps the most important lesson is that simple generalizations are tenuous. It is widely-accepted, for example, that photosynthesis and growth are usually more responsive to $\mathrm{CO}_{2}$ in $\mathrm{C}_{3}$ than $\mathrm{C}_{4}$ species when environmental conditions are near optimal for growth. It might, therefore, be expected that $\mathrm{C}_{3}$ species should increase at the expense of co-occurring $\mathrm{C}_{4}$ plants as $\mathrm{CO}_{2}$ concentration rises. That expectation frequently is supported (Bazzaz and Carlson 1984, Arp et al. 1993, Johnson et al. 1993), but there are exceptions. Basal cover of $\mathrm{C}_{3}$ Kentucky bluegrass ( $\mathrm{Poa}$ pratensis $\mathrm{L}$.) declined on $\mathrm{C}_{4}$-dominated tallgrass prairie when $\mathrm{CO}_{2}$ was elevated (Owensby et al. 1993b). Wong and Osmond (1991) grew a $C_{3}$ (wheat, Triticum aestivum L.) and $C_{4}$ species (Japanese millet, Echinochloa frumentacea Link) together under different light, $\mathrm{N}$, and $\mathrm{CO}_{2}$ treatments. Contribution of the $\mathrm{C}_{3}$ plant to species mixtures increased when $\mathrm{CO}_{2}$ was elevated, but only at high $\mathrm{N}$. The reverse occurred when $\mathrm{N}$ was low. In each experiment, effects of $\mathrm{CO}_{2}$ on the $\mathrm{C}_{3}$ species were minimal because other factors limited growth. Cover of Kentucky bluegrass on tallgrass prairie declined at elevated $\mathrm{CO}_{2}$ apparently because the short-statured grass was shaded by taller species or, perhaps, limited by low $\mathrm{N}$ availability. Similarly, Wong and Osmond (1991) found that $\mathrm{CO}_{2}$ concentration had little affect on the outcome of $\mathrm{C}_{3} / \mathrm{C}_{4}$ competition when light or $\mathrm{N}$ treatments created size inequities between species.

The lesson from these and similar experiments is clear. Rising $\mathrm{CO}_{2}$ will have little or no impact on a species' abundance when $\mathrm{CO}_{2}$-insensitive aspects of plant biology or ecology limit growth (e.g., Newton et al. 1994). Species abundances often are determined more by characteristics that influence plant access to essential resources like nitrogen and light and reaction to disturbances (stature, morphology, phenology) than by physiological traits that are sensitive to $\mathrm{CO}_{2}$ concentration (Díaz 1995).

In general, therefore, we should expect that effects of $\mathrm{CO}_{2}$ on plant species composition will be greatest when rising $\mathrm{CO}_{2}$ improves plant access to or use of the most limiting resource. On rangelands, the limiting resource is often water. Indeed, water balance is perhaps the most important factor influencing species distributions and abundances at the global scale (Woodward 1987b, Stephenson 1990). The distribution of plant formations in North America, for example, is highly correlated with 2 aspects of water balance, deficit (evaporative demand not met by available water) and actual evapotranspiration (Stephenson 1990). Vegetation in the southern U.S. changes from forest, to grassland, and finally to shrubland as actual evapotranspiration decreases and water deficit increases. The influence of water balance on vegetation is particularly evident on grasslands and shrublands. The distribution of grassland types is highly correlated with the seasonal distribution of precipitation and timing and duration of drought (Parton et al. 1994). Relatively small changes in factors affecting water balance could cause comparably large changes in the relative abundances of grasses and shrubs or other species on rangelands. Indeed, transition zones between grasslands and woodlands or forests may be among the first areas to experience species change as $\mathrm{CO}_{2}$ rises or climate changes (Sage 1996a).

Vegetation and water balance are coupled most directly through transpiration. At equilibrium, the leaf area of vegetation accumulates as existing species grow larger and new species are added until transpiration depletes available soil water (Woodward 1993, Neilson and Marks 1994). As leaf area index (LAI) increases, so does the height of vegetation (Woodward 1993) and the likelihood that plants must compete for light (Tilman 1988, Smith and Huston 1989). To the extent that rising $\mathrm{CO}_{2}$ decreases transpiration rate per unit leaf area and increases WUE, it will increase leaf area. These changes should, in turn, favor taller growth forms when competition for light is intense. On some rangelands, tallgrasses may replace mid-grasses, independently of photosynthetic pathway. On others, trees and shrubs may increase at the expense of grasses.

Relationships of water availability to potential LAI can be used to model or simulate the current distributions of forests (Neilson 1995). They might also predict vegetation on mesic grasslands and savannas where LAI is relatively high. On most other rangelands, LAI is smaller, annual and seasonal variation in precipitation is greater, and drought lasts longer. Relationships of water availability to leaf area are relatively poor predictors of vegetation in these ecosystems (Neilson 1995). In arid and semi-arid regions, a plant's success probably depends largely on its ability to acquire enough $\mathrm{C}$ during wet periods to replace maintenance and other losses when soil dries (e.g., Bunce et al. 1979) or survive low soil water levels (Harrington 1991).

Lethal water potentials explain the distributional limits of some species (Neilson and Wullstein 1983), but many plants may be restricted to soil water levels that are not directly lethal. Bunce et al. (1979) demonstrated that distribution of woody species along an aridity gradient correlated more closely with the point at which annual net $\mathrm{C}$ balance of leaves reached zero than with lethal water potentials. Other studies are consistent with the conclusion that success in arid regions is correlated with a positive $\mathrm{C}$ balance (Mooney and Dunn 1970, Orians and Solbrig 1977). Westoby (1980), for example, advanced a C balance model to explain the presence of different growth-forms on arid rangelands. In these areas, periods with favorable soil moisture conditions are separated by variable periods with no rainfall. Plants face a tradeoff between the ability to rapidly deploy photosynthetic tissues after rainfall (or sustain leaf area during drought) and maintain high photosynthetic rates when water is available (see also, Orians and Solbrig 1977). Different growth-forms are favored as soil water availability changes through cycles of precipitation and drought. 
The $\mathrm{C}$ balance of plants that experience frequent or extended drought will depend on several factors. Included are how quickly leaf area and photosynthesis change with soil water content, $\mathrm{C}$ uptake rates when water is available, and rates of soil water depletion (Westoby 1980). Information at different $\mathrm{CO}_{2}$ concentrations on the dynamics of leaf area and photosynthesis as soil water availability changes is sparse. Leaf photosynthesis of individually-grown plants sometimes declines more slowly as soil dries at elevated than the current $\mathrm{CO}_{2}$ concentration, but this usually reflects slower rates of transpiration and soil water depletion at higher $\mathrm{CO}_{2}$ concentrations. Leaf area in some ecosystems may increase to use available water, perhaps following species change, so rates of soil water depletion and the response of photosynthesis to declining water may not be greatly altered by atmospheric change. Higher $\mathrm{CO}_{2}$ may, therefore, be most beneficial to aridland plants when water is available.

There is evidence, however, that rising $\mathrm{CO}_{2}$ could also contribute to species change by improving plant tolerance of water stress. Marks and Strain (1989) found that raising $\mathrm{CO}_{2}$ from the current $350 \mathrm{ppm}$ to $650 \mathrm{ppm}$ almost doubled percentage survival of droughted aster (Aster pillosus) plants. Similarly, more than twice as many honey mesquite seedlings survived soil water depletion at 710 and 1,050 ppm than $350 \mathrm{ppm} \mathrm{CO}_{2}$ (Polley et al. 1996c). By increasing seedling survival during drought, rising $\mathrm{CO}_{2}$ could increase abundance of species that previously were excluded by low water availability.

Indirect or feedback effects of $\mathrm{CO}_{2}$ on the pattern or timing of water use by vegetation may prove as important to species change as direct effects of $\mathrm{CO}_{2}$ on growth. Water use efficiency, as discussed previously, usually increases with $\mathrm{CO}_{2}$ concentration. At the leaf level, this results from lower stomatal conductance and transpiration, higher photosynthesis, or a combination of the two. In many $\mathrm{C}_{3}$ plants, leaves fix $\mathrm{C}$ faster as $\mathrm{CO}_{2}$ rises, so part of the increase in $\mathrm{C}_{3}$ WUE usually results from higher photosynthetic rates. Increased photosynthesis may translate, in turn, into greater leaf area, partly offsetting effects of lower transpiration per unit leaf area on total water use (Carlson and Bunce 1996). When plants are limited by low $\mathrm{N}$ availability, phenology, or other factors, however, leaf growth may not increase enough to negate water savings from slower transpiration rates. In $\mathrm{C}_{3}$ annual grassland in California U.S.A., doubling $\mathrm{CO}_{2}$ concentration reduced stomatal conductance and transpiration of the dominant species, wild oat, by about $50 \%$, and increased water content in moderately productive sandstone-derived soil by $34 \%$ at season's end (Jackson et al. 1994, Field et al. 1995). The late-season increase in soil water content apparently contributed to increased growth of summer annuals (Chiariello and Field 1996). In most $\mathrm{C}_{4}$ plants, photosynthesis, growth, and leaf area are not very sensitive to $\mathrm{CO}_{2}$ when water is available. Higher $\mathrm{CO}_{2}$ increases $\mathrm{C}_{4}$ WUE primarily by reducing transpiration per unit leaf area (Kirkham et al. 1991, Knapp et al. 1994b, Polley et al. 1996a). The major benefit to $C_{4}$ plants occurs when rainfall declines and plants use water 'saved' during relatively wet periods to prolong growth (Owensby et al. 1993b; but see, Carlson and Bunce 1996). In the short-term, this temporary increase in soil water content did not greatly affect species composition on tallgrass prairie. In the longer term as seed from additional species are added, plants that are presently eliminated by drought may increase by exploiting water saved by grasses. Low water availability reduces survival of woody seedlings on some rangelands (Paulsen 1950, Harrington 1991, O'Connor 1995), so slower transpiration by grasses could favor woody invasion (Polley et al. 1996b). Alternatively, higher levels of soil water might contribute to an increase in water yield from mesic rangelands, as suggested by model simulations of a forested catchment (Hatton et al. 1992).

Shrubs and grasses co-exist on some rangelands because they use water from different soil depths (Knoop and Walker 1985, Sala et al. 1989). Grasses root more shallowly than some shrubs and use water from upper soil layers. Deeply-rooting shrubs survive largely on water that percolates below grass roots. The depth to which rainfall percolates depends partially on soil water content (Hanks and Ashcroft 1980). By reducing transpiration rates of grasses, rising $\mathrm{CO}_{2}$ concentration may slow the depletion of water in upper soil layers and increase deep percolation of subsequent precipitation. Deeply-rooting shrubs and other plants that require this water may be favored as a result (Polley et al. 1997b).

\section{A Challenge for Managers}

Atmospheric and possible climatic change pose novel challenges for managers of rangelands. Rising $\mathrm{CO}_{2}$ concentration may increase forage production, but also change plant species composition. Production and management systems that are tightly coupled to the current mix of plant species or growth forms could, therefore, be vulnerable.

A primary goal of rangeland management is 'sustainability', the maintenance of plant and animal production within bounds in the face of normal cycles of disturbances and weather (Chapin et al. 1996). Productivity and other 'ecosystem' processes, like element cycling, are regulated by what Chapin et al. (1996) term 'interactive controls': regional climate, soil resource availability, functional types of organisms, and disturbance regimes. Negative feedbacks that constrain changes in the 4 interactive controls serve to reduce variability in ecosystem processes and, thereby, foster sustainability. By contrast, factors that promote or strengthen positive feedbacks can alter controls and change system properties. On some grasslands, for example, the combination of low precipitation and soil water availability (climate, soil resources) and high flammability of grasses (type of organisms) leads to conditions (frequent fire, drought) that limit woody ingress and so prevent changes in the functional types of plants present. One way that this system of controls can be disrupted is by overgrazing and the positive feedbacks that ensue. Grazers remove leaves and so lessen both the fuel available for fire and rate at which soil water is transpired. Survival of woody plants is improved by the resulting decrease in fire frequency or intensity and increase in soil water content. As the woody invaders grow, they shade and further displace grasses, resulting in a positive feedback that amplifies changes initiated by overgrazing.

Impacts of $\mathrm{CO}_{2}$ enrichment are likely to be greatest when they reinforce other de-stabilizing changes. By increasing the growth rates of woody seedlings or improving their ability to survive drought, for instance, rising $\mathrm{CO}_{2}$ could act as a positive feedback to overgrazing in promoting woody invasion. In other systems, change resulting from $\mathrm{CO}_{2}$ enrichment could benefit livestock production.

One challenge for managers is to recognize conditions or events that may augment effects of $\mathrm{CO}_{2}$ enrichment and develop management strategies to either enhance or offset these effects, as appropriate. Required is an understanding of the causes of change in the rangeland of interest and how rising $\mathrm{CO}_{2}$ concentration is likely to interact with these causes. The recently advanced 'stateand-transition' model for management (Westoby et al. 1989) 
might be adapted to include effects of atmospheric change. The primary tools of rangeland managers, changes in the numbers and kinds of animals, timing of grazing, and use of fire, can be used to manipulate 2 of the 4 interactive controls, disturbance regime and the functional types of organisms present. The types of plants present could be further manipulated by seeding or with herbicides. Where cost effective, fertilization can be used to change soil resource availability. It will not always be cost-effective to manage for rangeland types that are not readily sustainable. Therefore, alternative means of harvesting plant production should also be considered.

\section{Conclusions}

Much has been learned about the effects of atmospheric $\mathrm{CO}_{2}$ concentration on plant physiology and how physiological changes influence plant growth. With knowledge of soil resource availability, we now can predict with reasonable confidence the shortterm (years to decade) response of plant production to a change in $\mathrm{CO}_{2}$ concentration. What we most lack is an understanding of the long-term (decades to centuries) consequences of greater $C$ availability for rangelands and other ecosystems. Slowly-changing processes, like those that determine $\mathrm{N}$ availability and cycling, may affect production as much in the long term as the rapidlychanging processes that have dominated research. We also know little of how interactions between $\mathrm{CO}_{2}$ enrichment and disturbance regimes will affect rangelands. Fire and herbivory (grazing), for example, are 2 of the principal controls on production and species abundances on rangelands, but interactions with $\mathrm{CO}_{2}$ concentration have scarcely been considered.

Effects of rising $\mathrm{CO}_{2}$ concentration on rangelands are likely to be numerous and varied, with secondary or indirect effects exerting as great an impact on these systems as the direct effects of $\mathrm{CO}_{2}$ on photosynthesis. Indirect effects of atmospheric change on fire frequency and intensity and soil water and $\mathrm{N}$ availability, for example, may prove as important to vegetation dynamics and production as the more direct and intensively-studied effects of $\mathrm{CO}_{2}$ on plant growth (Mayeux et al. 1994).

Consequences of atmospheric change for the species and intraspecific genetic composition of rangeland vegetation remain a major unknown. The way in which rangeland vegetation is reshuffled by global change will, to a large extent, determine the goods and services that humans derive from these systems. Because of the complexities of factors interacting with $\mathrm{CO}_{2}$, it is unlikely that vegetation change will always or even frequently follow simple predictions. We know from paleobotanical research that vegetative communities did not move as intact units during the past (Davis 1986). Novel species combinations are thus likely in the future. Because many rangelands are water-limited, it is likely that changes in plant water use and water balance will play a dominant role in vegetation dynamics as $\mathrm{CO}_{2}$ rises. Species change will probably be greatest or at least most rapid in relatively water-limited and moderately-disturbed ecosystems where positive effects of higher $\mathrm{CO}_{2}$ on plant water balance are greatest and competition for light is minimized. Greatest initial changes in species composition may occur at the transition between vegetation types, as between grasslands and woodlands or forests.

\section{Literature Cited}

Aber, J.D., J.M. Melillo, K.J. Nadelhoffer, J. Pastor, and R.D. Boone. 1991. Factors controlling nitrogen cycling and nitrogen saturation in northern temperate forest ecosystems. Ecol. Appl. 1:303-315.

Ackerly, D.D., J.S. Coleman, S.R. Morse, and F.A. Bazzaz. 1992. $\mathrm{CO}_{2}$ and temperature effects on leaf area production in two annual plant species. Ecol. 73:1260-1269.

Allen, L.H., Jr., E.C. Bisbal, K.J. Boote, and P.H. Jones. 1991. Soybean dry matter allocation under subambient and superambient levels of carbon dioxide. Agron. J. 83:875-883.

Amthor, J.S. 1991. Respiration in a future, higher $\mathrm{CO}_{2}$ world. Plant Cell Environ. 14:13-20.

Amthor, J.S. 1995. Terrestrial higher-plant response to increasing atmospheric $\left[\mathrm{CO}_{2}\right]$ in relation to the global carbon cycle. Global Change Biol. 1:243-274.

Amthor, J.S., G.W. Koch, and A.J. Bloom. 1992. $\mathrm{CO}_{2}$ inhibits respiration in leaves of Rumex crispus L. Plant Physiol. 98:757-760.

Anderson, R.C. 1982. An evolutionary model summarizing the roles of fire, climate, and grazing animals in the origin and maintenance of grasslands: an end paper, p. 297-308. In: J.R. Estes, R.J. Tyrl, and J.N. Brunken (eds.), Grasses and grasslands: systematics and ecology. Univ. of Oklahoma Press, Norman, Okla.

Arp, W.J., B.G. Drake, W.T. Pockman, P.S. Curtis, and D.F. Whigham. 1993. Interactions between $C_{3}$ and $C_{4}$ salt marsh plant species during four years of exposure to elevated atmospheric $\mathrm{CO}_{2}$. Vegetatio 104/105: 133-143.

Axelrod, D.I. 1985. Rise of the grassland biome, central North America. Bot. Rev. 51:163-201.

Baker, J.T., L.H. Allen, Jr., K.J. Boote, P. Jones, and J.W. Jones. 1990a. Rice photosynthesis and evapotranspiration in subambient, ambient, and superambient carbon dioxide concentrations. Agron. J. 82:834-840.

Baker, J.T., L.H. Allen, Jr., K.J. Boote, P. Jones, and J.W. Jones. 1990b. Developmental responses of rice to photoperiod and carbon dioxide concentration. Agr. For. Meteorol. 50:201-210.

Barnola, J.M., D. Raynaud, Y.S. Korotkevich, and C. Lorius. 1987. Vostok ice core provides 160,000 -year record of atmospheric $\mathrm{CO}_{2}$. Nature 329:408-414.

Bazzaz, F.A. 1990. The response of natural ecosystems to the rising global $\mathrm{CO}_{2}$ levels. Annu. Rev. Ecol. Syst. 21:167-196.

Bazzaz, F.A. and R.W. Carlson. 1984. The response of plants to elevated $\mathrm{CO}_{2}$. I. Competition among an assemblage of annuals at two levels of soil moisture. Oecologia 62:196-198.

Berner, R.A. 1990. Atmospheric carbon dioxide levels over phanerozoic time. Sci. 249:1382-1386.

Berner, R.A. 1992. Palaeo- $\mathrm{CO}_{2}$ and climate. Nature 358:114.

Berryman, C.A., D. Eamus, and G.A. Duff. 1994. Stomatal responses to a range of variables in two tropical tree species grown with $\mathrm{CO}_{2}$ enrichment. J. Exp. Bot. 45:539-546.

Bolker, B.M., S.W. Pacala, F.A. Bazzaz, C.D. Canham, and S.A. Levin. 1995. Species diversity and ecosystem response to carbon dioxide fertilization: conclusions from a temperate forest model. Global Change Biol. 1:373-381.

Briske, D.D. 1991. Developmental morphology and physiology of grasses, p. 85-108. In: R.K. Heitschmidt and J.W. Stuth (eds.), Grazing management: an ecological perspective. Timber Press, Portland, Ore.

Brouwer, R. 1983. Functional equilibrium: sense or nonsense. Neth. J. Agr. Sci. 31:335-348.

Bunce, J.A. 1990. Short and long term inhibition of respiratory carbon dioxide efflux by elevated carbon dioxide. Ann. Bot. 65:637-642.

Bunce, J.A., B.F. Chabot, and L.N. Miller. 1979. Role of annual leaf carbon balance in the distribution of plant species along an elevational gradient. Bot. Gaz. 140:288-294.

Caldwell, M.M., J.H. Richards, D.A. Johnson, R.S. Nowak, and R.S. Dzurec. 1981. Coping with herbivory: photosynthetic capacity and resource allocation in two semiarid Agropyron bunchgrasses. Decologia 50:14-24. 
Campbell, B.D., W.A. Laing, D.H. Greer, J.R. Crush, H. Clark, D.Y. Williamson, and M.D.J. Given. 1995. Variation in grassland populations and species and the implications for community responses to elevated $\mathrm{CO}_{2}$. J. Biogeog. 22:315-322.

Carlson, T.N. and J.A. Bunce. 1996. Will a doubling of atmospheric carbon dioxide concentration lead to an increase or a decrease in water consumption by crops? Ecol. Model. 88:241-246.

Cerling T.E., Y. Wang, and J. Quade. 1993. Expansion of $C_{4}$ ecosystems as an indicator of global ecological change in the late Miocene. Nature 361:344-345.

Chapin, F.S., III, M.S. Torn, and M. Tateno. 1996. Principles of ecosystem sustainability. Amer. Nat. 148:1016-1037.

Chiariello, N.R. and C.B. Field. 1996. Annual grassland responses to elevated $\mathrm{CO}_{2}$ in multiyear community microcosms, p. 139-157. In : Ch. Körner and F.A. Bazzaz (eds.), Carbon dioxide, populations, and communities. Academic Press, San Diego, Calif.

Coleman, J.S., L. Rochefort, F.A. Bazzaz, and F.I. Woodward. 1991. Atmospheric $\mathrm{CO}_{2}$, plant nitrogen status and the susceptibility of plants to an acute increase in temperature. Plant Cell Environ. 14:667-674.

Cure, J.D., T.W. Rufty, Jr., and D.W. Israel. 1989. Alterations in soybean leaf development and photosynthesis in a $\mathrm{CO}_{2}$-enriched atmosphere. Bot. Gaz. 150:337-345.

Curtis, P.S., L.M. Balduman, B.G. Drake, and D.F. Whigham. 1990 Elevated atmospheric $\mathrm{CO}_{2}$ effects on below-ground processes in $\mathrm{C}_{3}$ and $\mathrm{C}_{4}$ estuarine marsh communities. Ecol. 71:2001-2006.

Curtis, P.S., B.G. Drake, P.W. Leadley, W.J. Arp., and D.F Whigham. 1989. Growth and senescence in plant communities exposed to elevated $\mathrm{CO}_{2}$ concentrations on an estuarine marsh Oecologia 78:20-26.

Davis, M.B. 1986. Climatic instability, time lags, and community disequilibrium, p. 269-284. In: J. Diamond and T.J. Case (eds.), Community ecology. Harper \& Row, New York, N.Y

Delmas, R.J., J-M. Ascencio, and M. Legrand. 1980. Polar ice evidence that atmospheric $\mathrm{CO}_{2} 20,000$ yr BP was $50 \%$ of present. Nature 284:155-157.

DeLucia, E.H., T.W. Sasek, and B.R. Strain. 1985. Photosynthetic inhibition after long-term exposure to elevated levels of atmospheric $\mathrm{CO}_{2}$. Photosynth. Res. 7:175-184.

Diaz, S. 1995. Elevated $\mathrm{CO}_{2}$ responsiveness, interactions at the community level and plant functional types. J. Biogeog. 22:289-295.

Díaz, S., J.P. Grime, J. Harris, and E. McPherson. 1993. Evidence of a feedback mechanism linking plant response to elevated carbon dioxide. Nature 364:616-617.

Diemer, M.W. 1994. Mid-season gas exchange of an alpine grassland under elevated $\mathrm{CO}_{2}$. Oecologia 98:429-435.

Dippery, J.K., D.T. Tissue, R.B. Thomas, and B.R. Strain. 1995. Effects of low and elevated $\mathrm{CO}_{2}$ on $\mathrm{C}_{3}$ and $\mathrm{C}_{4}$ annuals. I. Growth and biomass allocation. Oecologia 101:13-20.

Drake, B.G. and P.W. Leadley. 1991. Canopy photosynthesis of crops and native plant communities exposed to long term elevated $\mathrm{CO}_{2}$ Plant Cell Environ.14:853-860.

Eamus, D., C.A. Berryman, and G.A. Duff. 1995. The impact of $\mathrm{CO}_{2}$ enrichment on water relations in Maranthes corymbosa and Eucalyptus tetrodonta. Aust. J. Bot. 43:273-282.

Ehleringer, J. and O. Björkman. 1977. Quantum yields for $\mathrm{CO}_{2}$ uptake in $\mathrm{C}_{3}$ and $\mathrm{C}_{4}$ plants: dependence on temperature, $\mathrm{CO}_{2}$ and $\mathrm{O}_{2}$ uptake. Plant Physiol.59:86-90.

Ehleringer, J.R., R.F. Sage, L.B. Flanagan, and R.W. Pearcy, 1991. Climate change and the evolution of $\mathrm{C}_{4}$ photosynthesis. Trends Ecol. Evol. 6:95-99.

Eisele, K.A., D.S. Schimel, L.A. Kapustka, and W.J. Parton. 1989. Effects of available $P$ and N:P ratios on non-symbiotic dinitrogen fixation in tallgrass prairie soils. Oecologia 79:471-474.

Fajer, E.D., M.D. Bowers, and F.A. Bazzaz. 1991. Performance and allocation patterns of the perennial herb, Plantago lanceolata, in response to simulated herbivory and elevated $\mathrm{CO}_{2}$ environments. Oecologia 87:37-42.

Farnsworth, E.J. and F.A. Bazzaz. 1995. Inter- and intra-generic differences in growth, reproduction, and fitness of nine herbaceous annual species grown in elevated $\mathrm{CO}_{2}$ environments. Oecologia 104:454-466.
Farrar, J.L. and M.L. Williams. 1991. The effects of increased atmospheric carbon dioxide and temperature on carbon partitioning, sourcesink relations and respiration. Plant Cell Environ. 14:819-830.

Field, C.B., R.B. Jackson, and H.A. Mooney. 1995. Stomatal responses to increased $\mathrm{CO}_{2}$ : implications from the plant to the global scale. Plant Cell Environ. 18:1214-1225.

Fredeen, A.L., G.W. Koch, and C.B. Field. 1995. Effects of atmospheric $\mathrm{CO}_{2}$ enrichment on ecosystem $\mathrm{CO}_{2}$ exchange in a nutrient and water limited grassland. J. Biogeog. 22:215-219.

Friedli, H., H. Lötscher, H. Oeschger, U. Siegenthaler, and B. Stauffer. 1986. Ice core record of the ${ }^{13} \mathrm{C}^{12} \mathrm{C}$ ratio of atmospheric $\mathrm{CO}_{2}$ in the past two centuries. Nature 324:237-238.

Gifford, R.M. 1977. Growth pattern, carbon dioxide exchange and dry weight distribution in wheat growing under differing photosynthetic environments. Aust. J. Plant Physiol. 4:99-110.

Gorissen, A., J.H. van Ginkel, J.J.B. Keurentjes, and J.A. van Veen. 1995. Grass root decomposition is retarded when grass has been grown under elevated $\mathrm{CO}_{2}$. Soil Biol. Biochem. 27:117-120.

Grulke, N.E., G.H. Riechers, W.C. Oechel, U. Huelm, and C. Jaeger. 1990. Carbon balance in tussock tundra under ambient and elevated atmospheric $\mathrm{CO}_{2}$. Oecologia 83:485-494.

Ham, J.M., C.E. Owensby, P.I. Coyne, and D.J. Bremer. 1995. Fluxes of $\mathrm{CO}_{2}$ and water vapor from a prairie ecosystem exposed to ambient and elevated atmospheric $\mathrm{CO}_{2}$. Agr. For. Meterorol. 77:73-93.

Hanks, R.J. and G.L. Asheroft. 1980. Applied soil physics. SpringerVerlag, Berlin, Germany.

Harrington, G.N. 1991. Effects of soil moisture on shrub seedling survival in a semi-arid grassland. Ecol. 72:1138-1149.

Hatton, T.J., J. Walker, W.R. Dawes, and R.X. Dunin. 1992. Simulations of hydroecological responses to elevated $\mathrm{CO}_{2}$ at the catchment scale. Aust. J. Bot. 40:679-696.

Hunt, H.W. 1977. A simulation model for decomposition in grasslands. Ecol. 58:469-484.

Bunt, H.W., E.T. Elliott, J.K. Detling, J.A. Morgan, and D.X. Chen. 1996. Responses of $\mathrm{a}_{3}$ and a $\mathrm{C}_{4}$ perennial grass to elevated $\mathrm{CO}_{2}$ and temperature under different water regimes. Global Change Biol. $2: 35-47$.

Hunt, H.W., E.R. Ingham, D.C. Coleman, E.T. Elliott, and C.P.P. Reid. 1988. Nitrogen limitation of production and decomposition in prairie, mountain meadow, and pine forest. Ecol. 69:1009-1016.

Hunt, H.W., M.J. Trlica, E.F. Redente, J.C. Moore, J.K. Detling, T.G.F. Kittle, D.E. Walter, M.C. Fowler, D.A. Klein, and E.T Elliott. 1991. Simulation model for the effects of climate change on temperate grassland ecosystems. Ecol. Model. 53:205-246.

Idso, K.E. and S.B. Idso. 1994. Plant responses to atmospheric $\mathrm{CO}_{2}$ enrichment in the face of environmental constraints: a review of the past 10 years' research. Agr. For. Meteorol. 69:153-203.

Idso, S.B., B.A. Kimball, M.G. Anderson, and J.R. Mauney. 1987. Effects of atmospheric $\mathrm{CO}_{2}$ enrichment on plant growth: The interactive role of air temperature. Agr. Ecosyst. Environ. 20:1-10.

Jackson, R.B., Y. Luo, Z.G. Cardon, O.E. Sala, C.B. Field, and H.A. Mooney. 1995. Photosynthesis, growth and density for the dominant species in a $\mathrm{CO}_{2}$-enriched grassland. J. Biogeog. 22:221-225.

Jackson, R.B., O.E. Sala, C.B. Field, and H.A. Mooney. 1994. $\mathrm{CO}_{2}$ alters water use, carbon gain, and yield for the dominant species in a natural grassland. Oecologia 98:257-262.

Jenkinson, D.S., J.M. Potts, J.N. Perry, V. Barnett, K. Coleman, and A.E. Johnston. 1994. Trends in herbage yields over the last century on the Rothansted Long-term Continuous Hay Experiment. J. Agr. Sci. Camb. 122:365-374.

Johnson, H.B., H.W. Polley, and H.S. Mayeux. 1993. Increasing $\mathrm{CO}_{2}$ and plant-plant interactions: effects on natural vegetation. Vegetatio 104/105:157-170.

Jones, M.B., J.C. Brown, A. Raschi, and F. Miglietta. 1995. The effects on Arbutus unedo L. of long-term exposure to elevated $\mathrm{CO}_{2}$. Global Change Biol. 1:295-302.

Jongen, M., M.B. Jones, T. Hebeisen, H. Blum, and G. Hendrey. 1995. The effects of elevated $\mathrm{CO}_{2}$ concentrations on the root growth of Lolium perenne and Trifolium repens grown in a FACE system. Global Change Biol. 1:361-371. 
Jouzel, J., N.I. Barkov, J.M. Barnola, M. Bender, J. Chappellaz, C. Genthon, V.M. Kotlyakov, V. Lipenkov, C. Lorius, J.R. Petit, D. Raynaud, G. Raisbeck, C. Ritz, T. Sowers, M. Stievenard, F. Yiou, and P. Yiou. 1993. Extending the Vostok ice-core record of palaeoclimate to the penultimate glacial period. Nature 364:407-412.

Keeling, C.D. and T.P. Whorf. 1994. Atmospheric $\mathrm{CO}_{2}$ records from sites in the SIO air sampling network, p. 16-26. In: T.A. Boden, D.P. Kaiser, R.J. Sepanski, and F.W. Stoss (eds.), Trends '93: A compendium of data on global change. Carbon Dioxide Information Analysis Center. Oak Ridge Nat. Lab., Oak Ridge, Tenn.

Kemp, P.R., D.G. Waldecker, C.E. Owensby, J.F. Reynolds, and R.A. Virginia. 1994. Effects of elevated $\mathrm{CO}_{2}$ and nitrogen fertilization pretreatments on decomposition of tallgrass prairie leaf litter. Plan Soil 165:115-127.

Kirkham, M.B., H. He, T.P. Bolger, D.J. Lawlor, and E.T. Kanemasu. 1991. Leaf photosynthesis and water use of big bluestem under elevated carbon dioxide. Crop Sci. 31:1589-1594.

Kitajima, K. and D. Tilman. 1996. Seed banks and seedling establishment on an experimental productivity gradient. Oikos 76:381-391.

Knapp, A.K., M. Cocke, E.P. Hamerlynck, and C.E. Owensby. 1994a. Effect of elevated $\mathrm{CO}_{2}$ on stomatal density and distribution in a $\mathrm{C}_{4}$ grass and a $\mathrm{C}_{3}$ forb under field conditions. Ann. Bot. 74:595-599.

Knapp, A.K., J.T. Fahnestock, and C.E. Owensby. 1994b. Elevated atmospheric $\mathrm{CO}_{2}$ alters stomatal responses to variable sunlight in a $\mathrm{C}_{4}$ grass. Plant Cell Environ. 17:189-195.

Knapp, A.K., E.P. Hamerlynck, and C.E. Owensby. 1993. Photosynthetic and water relations responses to elevated $\mathrm{CO}_{2}$ in the $\mathrm{C}_{4}$ grass Andropogon gerardii. Int. J. Plant Sci. 154:459-466.

Knoop, W.T. and B.H. Walker. 1985. Interactions of woody and herbaceous vegetation in a southern African savanna. J. Ecol. 73:235-253.

Körner, Ch. and F. Miglietta. 1994. Long term effects of naturally elevated $\mathrm{CO}_{2}$ on mediterranean grassland and forest trees. Oecologia 99:343-351.

Larigauderie, A., D.W. Hilbert, and W.C. Oechel. 1988. Effect of $\mathrm{CO}_{2}$ enrichment and nitrogen availability on resource acquisition and resource allocation in a grass, Bromus mollis. Oecologia 77:544-549.

Lasaga, A.C., R.A. Berner, and R.M. Garrels. 1985. An improved geochemical model of atmospheric $\mathrm{CO}_{2}$ fluctuations over the past 100 million years, p. 397-411. In: E.T. Sundquist and W.S. Broecker (eds.), The carbon cycle and atmospheric $\mathrm{CO}_{2}$ : natural variations archean to present. Amer. Geophysical Union, Washington, D.C.

Lauenroth, W.K. 1979. Grassland primary production: North American grasslands in perspective, p. 3-24. In: N. French (ed.), Perspectives in grassland ecology. Springer-Verlag, New York, N.Y.

Long, S.P. 1991. Modification of the response of photosynthetic productivity to rising temperature by atmospheric $\mathrm{CO}_{2}$ concentrations: Has its importance been underestimated? Plant Cell Environ.14:729-739.

Long, S.P. and B.G. Drake. 1993. Photosynthetic $\mathrm{CO}_{2}$ assimilation and rising atmospheric $\mathrm{CO}_{2}$ concentrations. Commissioned review, $p$. 69-107. In: N.R. Baker and H. Thomas (eds.), Topics in photosynthesis, Vol. 11. Elsevier, Amsterdam, The Netherlands.

Long, S.P. and P.R. Hutchin. 1991. Primary production in grasslands and coniferous forests with climate change: an overview. Ecol. Appl. 1:139-156.

Long, S.P., E. Gracia Moya, S.K. Imbamba, A. Kamnalrut, M.T.F. Piedade, J.M.O. Scurlock, Y.K. Shen, and D.O. Hall. 1989. Primary productivity of natural grass ecosystems of the tropics: A reappraisal. Plant Soil 115:155-166.

Luo, Y., R.B. Jackson, C.B. Field, and H.A. Mooney. 1996. Elevated $\mathrm{CO}_{2}$ increases below-ground respiration in California grasslands. Oecologia 108:130-137.

McConnaughay, K.D.M., S.L. Bassow, G.M. Berntson, and F.A. Bazzaz. 1996. Leaf senescence and decline of end-of-season gas exchange in five temperate deciduous tree species grown in elevated $\mathrm{CO}_{2}$ concentrations. Global Change Biol. 2:25-33.

McNaughton, K.G. and P.G. Jarvis. 1991. Effects of spatial scale on stomatal control of transpiration. Agr. For. Meteorol. 54:279-301.

McNaughton, S.J., R.W. Ruess, and S.W. Seagle. 1988. Large mammals and process dynamics in African ecosystems. BioSci. 38:794-800.
Malone, S.R., H.S. Mayeux, H.B. Johnson, and H.W. Polley. 1993. Stomatal density and aperature length in four plant species grown across a subambient $\mathrm{CO}_{2}$ gradient. Amer. J. Bot. 80:1413-1418.

Marks, S. and B.R. Strain. 1989. Effects of drought and $\mathrm{CO}_{2}$ enrichment on competition between two old-field perennials. New Phytol. 111:181-186.

Mayeux, H.S., H.B. Johnson, and H.W. Polley. 1994. Potential interactions between global change and intermountain annual grasslands, $p$. 95-100. In: S.B. Monsen and S.G. Kitchen (eds.), Proceedings: Ecology and Management of Annual Rangelands. USDA, Forest Service, Intermountain Res. Sta., Ogden, Ut.

Medina, E. 1982. Physiological ecology of neotropical savanna plants, p. 308-335. In: B.J. Huntly and B.H. Walker (eds.), Ecology of tropical savannas. Springer-Verlag, Berlin, Germany.

Miao, S.L., P.M. Wayne, and F.A. Bazzaz. 1992. Elevated $\mathrm{CO}_{2}$ differentially alters the responses of coocurring birch and maple seedlings to a moisture gradient. Oecologia 90:300-304.

Mooney, H.A. 1972. The carbon balance of plants. Annu. Rev. Ecol. Syst. 3:315-346.

Mooney, H.A. and E.L. Dunn. 1970. Photosynthetic systems of Mediterranean-climate shrubs and trees of California and Chile. Amer. Nat. 104:447-453.

Morgan, J.A., H.W. Hunt, C.A. Monz, and D.R. Lecain. 1994a. Consequences of growth at two carbon dioxide concentrations and two temperatures for leaf gas exchange in Pascopyrum smithii $\left(\mathrm{C}_{3}\right)$ and Bouteloua gracilis $\left(\mathrm{C}_{4}\right)$. Plant Cell Environ. 17:1023-1033.

Morgan, J.A., W.G. Knight, L.M. Dudley, and H.W. Hunt. 1994b. Enhanced root system C-sink activity, water relations and aspects of nutrient acquisition in mycotrophic Bouteloua gracilis subjected to $\mathrm{CO}_{2}$ enrichment. Plant Soil 165:139-146.

Morison, J.I.L. 1987. Intercellular $\mathrm{CO}_{2}$ concentration and stomatal response to $\mathrm{CO}_{2}$, p. 229-251. In: E. Zeiger, G.D. Farquhar, and I. Cowan (eds.), Stomatal function. Stanford University Press, Stanford, Calif.

Morison, J.I.L. and R.M. Gifford. 1984. Plant growth and water use with limited water supply in high $\mathrm{CO}_{2}$ concentrations. I. Leaf area, water use and transpiration. Aust. J. Plant Physiol. 11:361-374.

Morse, S.R., P. Wayne, S.L. Miao, and F.A. Bazzaz. 1993. Elevated $\mathrm{CO}_{2}$ and drought alter tissue water relations of birch (Betula populifolia Marsh.) seedlings. Oecologia 95:599-602.

Navas, M.L., J.L. Guillerm, J. Fabreguettes, and J. Roy. 1995. The influence of elevated $\mathrm{CO}_{2}$ on community structure, biomass and balance of mediterranean old-field microcosms. Global Change Biol. 1:325-335.

Neales, T.F. and A.O. Nicholls. 1978. Growth responses of young wheat plants to a range of ambient $\mathrm{CO}_{2}$ levels. Aust. J.Plant Physiol. 5:45-59.

Neilson, R.P. 1995. A model for predicting continental-scale vegetation distribution and water balance. Ecol. Appl. 5:362-385.

Neilson, R.P. and D. Marks. 1994. A global perspective of regional vegetation and hydrologic sensitivities from climatic change. J. Veg. Sci. 5:715-730.

Neilson, R.P. and L.H. Wullstein. 1983. Biogeography of two southwest American oaks in relation to atmospheric dynamics. J. Biogeog.10:275-297.

Newton, P.C.D., H. Clark, C.C. Bell, E.M. Glasgow, and B.D. Campbell. 1994. Effects of elevated $\mathrm{CO}_{2}$ and simulated seasonal changes in temperature on the species composition and growth rates of pasture turves. Ann. Bot. 73:53-59.

Newton, P.C.D., H. Clark, C.C. Bell, E.M. Glasgow, K.R. Tate, D.J . Ross, G.W. Yeates, and S. Saggar. 1995. Plant growth and soil processes in temperate grassland communities at elevated $\mathrm{CO}_{2} . \mathrm{J}$. Biogeog. 22:235-240.

Nie, D., H. He, M.B. Kirkham, and E.T. Kanemasu. 1992a. Photosynthesis of a $\mathrm{C}_{3}$ and a $\mathrm{C}_{4}$ grass under clevated $\mathrm{CO}_{2}$. Photosynth. 26:189-195.

Nie, D., H. He, G. Mo, M.B. Kirkham, and E.T. Kanemasu. 1992 b. Canopy photosynthesis and evapotranspiration of rangeland plants under doubled carbon dioxide in closed-top chambers. Agr. For. Meteorol. 61:205-217. 
O'Connor, T.G. 1995. Acacia karroo invasion of grassland: environmental and biotic effects influencing seedling emergence and establishment. Oecologia 103:214-223.

Oechel, W.C., S. Cowles, N. Grulke, S.J. Hastings, B. Lawrence, T. Prudhomme, G. Riechers, B. Strain, D. Tissue, and G. Vourlitis. 1994. Transient nature of $\mathrm{CO}_{2}$ fertilization in Arctic tundra. Nature 371:500-503.

O'Neill, E.G. and R.J. Norby. 1996. Litter quality and decomposition rates of foliar litter produced under $\mathrm{CO}_{2}$ enrichment, p. 87-103. In: G.W. Koch and H.A. Mooney (eds.), Carbon dioxide and terrestrial ecosystems. Academic Press, San Diego, Calif.

Orians, G.H. and O.T. Solbrig. 1977. A cost-income model of leaves and roots with special reference to arid and semiarid areas. Amer. Nat. 111:677-690.

Owensby, C.E., L.M. Auen, and P.I. Coyne. 1994. Biomass production in a nitrogen-fertilized, tallgrass prairie ecosystem exposed to ambient and elevated levels of $\mathrm{CO}_{2}$. Plant Soil 165:105-113.

Owensby, C.E., R.C. Cochran, and L.M. Auen. 1996. Effects of elevated carbon dioxide on forage quality for ruminants, p. 363-371. In: Ch. Kömer and F.A. Bazzaz (eds.), Carbon dioxide, populations, and communities. Academic Press, San Diego, Calif.

Owensby, C.E., P.I. Coyne, and L.M. Auen. 1993a. Nitrogen and phosphorus dynamics of a tallgrass prairie ecosystem exposed to elevated carbon dioxide. Plant Cell Environ. 16:843-850.

Owensby, C.E., P.I. Coyne, J.M. Ham, L.A. Auen, and A.K. Knapp. 1993b. Biomass production in a tallgrass prairie ecosystem exposed to ambient and elevated $\mathrm{CO}_{2}$. Ecol. Appl. 3:644-653.

Parton, W.J., D.S. Ojima, and D.S. Schimel. 1994. Environmental change in grasslands: assessment using models. Climatic Change 28:111-141.

Parton, W.J., D.S. Schimel, C.V. Cole, and D.S. Ojima. 1987. Analysis of factors controlling soil organic matter levels in Great Plains grasslands. Soil Sci. Soc. Amer. J. 51:1173-1179.

Paulsen, H.A., Jr. 1950. Mortality of velvet mesquite seedlings. J. Range Manage. 3:281-286.

Pearcy, R.W. and J. Ehleringer. 1984. Comparative ecophysiology of $\mathrm{C}_{3}$ and $\mathrm{C}_{4}$ plants. Plant Cell Environ. 7:1-13.

Pickett, S.T.A., S.L. Collins, and J.J. Armesto. 1987. A hierarchical consideration of causes and mechanisms of succession. Vegetatio 69:109-114.

Polley, H.W., H.B. Johnson, B.D Marino, and H.S. Mayeux. 1993. Increase in $\mathrm{C}_{3}$ plant water-use efficiency and biomass over Glacial to present $\mathrm{CO}_{2}$ concentrations. Nature 361:61-64.

Polley, H.W., H.B. Johnson, and H.S. Mayeux. 1992. Growth and gas exchange of oats (Avena sativa) and wild mustard (Brassica kaber) at subambient $\mathrm{CO}_{2}$ concentrations. Int. J. Plant Sci. 153:453-461

Polley, H.W., H.B. Johnson, and H.S. Mayeux. 1994. Increasing $\mathrm{CO}_{2}$ : comparative responses of the $\mathrm{C}_{4}$ grass Schizachyrium and grassland invader Prosopis. Ecol. 75:976-988.

Polley, H.W., H.B. Johnson, and H.S. Mayeux. 1995. Nitrogen and water requirements of $\mathrm{C}_{3}$ plants grown at glacial to present carbon dioxide concentrations. Funct. Ecol. 9:86-96.

Polley, H.W., H.B. Johnson, and H.S. Mayeux. 1997a. Leaf physiology, production, water use, and nitrogen dynamics of the grassland invader Acacia smallii at elevated $\mathrm{CO}_{2}$ concentrations. Tree Physiol. 17:89-96.

Polley, H.W., H.B. Johnson, H.S. Mayeux, D.A. Brown, and J.W.C. White. 1996a. Leaf and plant water use efficiency of $\mathrm{C}_{4}$ species grown at glacial to elevated $\mathrm{CO}_{2}$ concentrations. Int. J. Plant Sci. 157:164-170.

Polley, H.W., H.B. Johnson, H.S. Mayeux, and C.R. Tischler. 1996b. Are some of the recent changes in grassland communities a response to rising $\mathrm{CO}_{2}$ concentrations?, p. 177-195. In: Ch. Körner and F.A. Bazzaz (eds.), Carbon dioxide, populations, and communities. Academic Press, San Diego, Calif.

Polley, H.W., H.B. Johnson, H.S. Mayeux, C.R. Tischler, and D.A. Brown. 1996c. Carbon dioxide enrichment improves growth, water relations and survival of droughted honey mesquite (Prosopis glandulosa) seedlings. Tree Physiol. 16:817-823.
Polley, H.W., H.S. Mayeux, H.B. Johnson, and C.R. Tischler. 1997b. Viewpoint: Atmospheric $\mathrm{CO}_{2}$, soil water and shrub/grass ratios on rangelands. J. Range Manage., 50:278-284.

Poorter, H. 1993. Interspecific variation in the growth response of plants to an elevated ambient $\mathrm{CO}_{2}$ concentration. Vegetatio 104/105:77-97.

Poorter, H. and C. Remkes. 1990. Leaf area ratio and net assimilation rate of 24 wild species differing in relative growth rate. Oecologia 83:553-559.

Rice, C.W., F.O. Garcia, C.O. Hampton, and C.E. Owensby. 1994. Soil microbial response in tallgrass prairie to elevated $\mathrm{CO}_{2}$. Plant Soil 165:67-74.

Ritchie, M.E. and D. Tilman. 1995. Responses of legumes to herbivores and nutrients during succession on a nitrogen-poor soil. Ecol. 76:2648-2655.

Rogers, H.H., G.B. Runion, and S.V. Krupa. 1994. Plant responses to atmospheric $\mathrm{CO}_{2}$ enrichment with emphasis on roots and the rhizosphere. Environ. Pollut. 83:155-189.

Rowland-Bamford, A.J., C. Nordenbrock, J.T. Baker, G. Bowes, and L.H. Allen, Jr. 1990. Changes in stomatal density in rice grown under various $\mathrm{CO}_{2}$ regimes with natural solar radiation. Environ. Exper. Bot. 30:175-180.

St. Omer, L. and S.M. Horvath. 1983. Elevated carbon dioxide concentrations and whole plant senescence. Ecol. 64:1311-1314.

Sage, R.F. 1994. Acclimation of photosynthesis to increasing atmospheric $\mathrm{CO}_{2}$ : the gas exchange perspective. Photosyn. Res. 39:351-368.

Sage, R.F. 1996a. Atmospheric modification and vegetation response to environmental stress. Global Change Biol. 2:79-83.

Sage, R.F. 1996b. Modification of fire disturbance by elevated $\mathrm{CO}_{2}, \mathrm{p}$. 231-249. In: Ch. Körner and F.A. Bazzaz (eds.), Carbon dioxide, populations, and communities. Academic Press, San Diego, Calif.

Sage, R.F., T.D. Sharkey, and J.R. Seeman. 1989. Acclimation of photosynthesis to elevated $\mathrm{CO}_{2}$ in five $\mathrm{C}_{3}$ species. Plant Physiol. 89:590-596.

Sala, O.E., R.A. Golluscio, W.K. Lauenroth, and A. Soriano. 1989. Resource partitioning between shrubs and grasses in the Patagonian steppe. Oecologia 81:501-505.

Schimel, D.S., W.J. Parton, T.G.F. Kittel, D.S. Ojima, and C.V. Cole. 1990. Grassland biogeochemistry: links to atmospheric processes. Climatic Change 17:13-25.

Seastedt, T.R., J.M. Briggs, and D.J. Gibson. 1991. Controls of nitrogen limitation in tallgrass prairie. Oecologia 87:72-79.

Schäppi, B. and Ch. Körner. 1996. Growth responses of an alpine grassland to elevated $\mathrm{CO}_{2}$. Oecologia 105:43-52.

Sharkey, T.D. 1988. Estimating the rate of photorespiration in leaves. Physiol. Plant. 73:147-152

Sionit, N., B.R. Strain, H. Hellmers, and P.J. Kramer. 1981. Effects of atmospheric $\mathrm{CO}_{2}$ concentration and water stress on water relations of wheat. Bot. Gaz. 142:191-96.

Smeins, F.E. 1983. Origin of the brush problem a geographical and ecological perspective of contemporary distributions, p. 5-16. In: Proceedings Brush management symposium. Texas Tech Univ. Press, Lubbock, Tex.

Smith, B.N. 1976. Evolution of $\mathrm{C}_{4}$ photosynthesis in response to changes in carbon and oxygen concentration in the atmosphere through time. BioSystems 8:24-32.

Smith, S.D, B.R. Strain, and T.D. Sharkey. 1987. Effects of $\mathrm{CO}_{2}$ enrichment on four Great Basin grasses. Funct. Ecol. 1:139-143.

Smith, T. and M. Huston. 1989. A theory of the spatial and temporal dynamics of plant communities. Vegetatio 83:49-69.

Spencer, W. and G. Bowes. 1986. Photosynthesis and growth of water hyacinth under $\mathrm{CO}_{2}$ enrichment. Plant Physiol. 82:528-533

Stephenson, N.L. 1990. Climatic control of vegetation distribution: the role of the water balance. Amer. Nat. 135:649-670.

Stitt, M. 1991. Rising $\mathrm{CO}_{2}$ levels and their potential significance for carbon flow in photosynthetic cells. Plant Cell Environ.14:741-762.

Stoddart, L.A., A.D. Smith, and T.W. Box. 1975. Range management. McGraw-Hill, New York, N.Y.

Thomas, B.A. and R.A. Spicer. 1987. The evolution and paleobiology of land plants. Croom Helm Publishers, London, England. 
Tilman, D. 1988. Plant strategies and the dynamics and structure of plant communities. Princeton Univ. Press, Princeton, N.J.

Tilman, D. 1993. Species richness of experimental productivity gradients: how important is colonization limitation? Ecol. 74:2179-2191.

Tilman, D. 1996. Biodiversity: population versus ecosystem stability. Ecol. 77:350-363.

Tischler, C.R., H.W. Polley, H.B. Johnson, and H.S. Mayeux. 1996. Effects of elevated concentrations of carbon dioxide on seedling growth of mesquite and huisache, p. 246-248. In: J.R. Barrow, E.D. McArthur, R.E. Sosebee and R.J. Tausch (eds.), Proceedings: Symposium on shrubland ecosystem dynamics in a changing climate. USDA, Forest Service, Intermountain Research Station, Ogden, Ut.

Tolley, L.C. and B.R. Strain. 1985. Effects of $\mathrm{CO}_{2}$ enrichment and water stress on gas exchange of Liquidambar styraciflua and Pinus taeda seedlings grown under different irradiance levels. Oecologia 65:166-172.

Trabalka, J.R., J.A. Edmonds, J.M. Reilly, R.H. Gardner, and D.E. Reichle. 1986. Atmospheric $\mathrm{CO}_{2}$ projections with globally averaged carbon cycle models, p. 534-560. In: J.R. Trabalka and D.E. Reichle (eds.), The changing carbon cycle: a global analysis. Springer-Verlag, New York, N.Y.

Upchurch, G.R. and J.A. Wolfe. 1987. Mid-Cretaceous to early Tertiary vegetation and climate: evidence from fossil leaves and woods, p. 75-105. In: E.M. Friis, W.G. Chaloner, and P.R. Crane (eds.), The origins of angiosperms and their biological consequences. Cambridge Univ. Press, Cambridge, Mass.

Westoby, M. 1980. Elements of a theory of vegetation dynamics in arid rangelands. Israel J. Bot. 28:169-194.
Westoby, M., B. Walker, and I. Noy-Meir. 1989. Opportunistic management for rangelands not at equilibrium. J. Range Manage. 42:266-274.

Wilsey, Bu., S.J. McNaughton, and J.S. Coleman. 1994. Will increases in atmospheric $\mathrm{CO}_{2}$ affect regrowth following grazing in $\mathrm{C}_{4}$ grasses from tropical grasslands? A test with Sporobolus kentrophyllus. Oecologia 99:141-144.

Wong, S.C. 1979. Elevated atmospheric partial pressure of $\mathrm{CO}_{2}$ and plant growth. I. Interactions of nitrogen nutrition and photosynthetic capacity in $C_{3}$ and $C_{4}$ plants. Oecologia 44:68-74.

Wong, S.C. and C.B. Osmond. 1991. Elevated atmospheric partial pressure of $\mathrm{CO}_{2}$ and plant growth. III. Interactions between Triticum aestivum $\left(\mathrm{C}_{3}\right)$ and Echinochloa frumentacea $\left(\mathrm{C}_{4}\right)$ during growth in mixed culture under different $\mathrm{CO}_{2}, \mathrm{~N}$ nutrition and irradiance treatments, with emphasis on below-ground responses estimated using the $\delta^{13} \mathrm{C}$ value of root biomass. Aust. J. Plant Physiol. 18:137-152.

Woodward, F.I. 1987a. Stomatal numbers are sensitive to increases in $\mathrm{CO}_{2}$ from pre-industrial levels. Nature 327:617-618.

Woodward, F.I. 1987b. Climate and plant distribution. Cambridge Univ. Press, Cambridge, Mass.

Woodward, F.I. 1993. Leaf response to the environment and extrapolation to larger scales, p. 71-100. In: A.M. Solomon and H.H. Shugart (eds.), Vegetation dynamics and global change. Chapman and Hall, New York, N.Y.

Woodward, F.I. and F.A. Bazzaz. 1988. The responses of stomatal density to $\mathrm{CO}_{2}$ partial pressure. J. Exp. Bot. 39:1771-1781.

Zak, D.R., K.S. Pregitzer, P.S. Curtis, J.A. Teeri, R. Fogel, and D.I. Randlett. 1993. Elevated atmospheric $\mathrm{CO}_{2}$ and feedback between carbon and nitrogen cycles. Plant Soil 151:105-117. 